\title{
Kokoelmakokonaisuuden analyysi tutkimuksen testaajana
}

\section{Tapausesimerkkinä Edith Södergranin Framtidens skugga (1920'}

Tarkastelen artikkelissani, kuinka kokoelmakokonaisuuden analyysilla voidaan haastaa tutkimuksellisia ideoita. Tutkimuskohteeni on modernistiklassikko Edith Södergranin runokokoelma Framtidens skugga (1920), jonka puhujia ja näiden muodostamia puhuja-asemia analysoin runo runolta. Analyysissani arvioin ennen kaikkea Torsten Petterssonin Gåtans namn -teoksessa (200I) esittämää ideaa siitä, että Södergranin tuotantoon kuuluu olennaisesti tietoinen ja itseironinen leikki erilaisilla maailmankatsomuksilla ikään kuin ne olisivat konstruktioita. Tarkastelussani kokoelma paljastuu jännitteiseksi, eri katsomuksellisia näkökantoja rinnakkain asettelevaksi kokonaisuudeksi. Osoitan runoanalyyseillani, että Petterssonin idea kuvaa vain osittain Södergranin kokoelman jäsentymistä. Kokoelman viimeisessä osastossa totuus ja resignaatio syrjäyttävät itseironisen leikin. Samalla analyysini tarkentaa Södergran-tutkimuksessa vallalla ollutta näkemystä runoilijan tuotannon aatteellisesta ja tyylillisestä periodisoinnista.

Kokoelmakokonaisuuden problematiikka on Edith Södergranin tuotannosta tehdyssä vuosikymmenten mittaisessa tutkimuksessa miltei käsittelemätön aihe, samoin kuin se on yhä harvinaisuus kansainvälisessä poetiikantutkimuksessa. ${ }^{2}$ Jo varhaisimmat laajat Södergran-tutkimukset, kuten Gunnar Tideströmin (1949) ja Olof Enckellin (1949) monografiat käyvät läpi Södergranin tuotannon teos teokselta ja tarkastelevat tyylintutkimuksellisesti niille ominaisia piirteitä ja runotyyppejä. Silti niistä tai myöhemmistä Södergran-tutkimuksista ei löydy kokoelmakokonaisuuden analyysia painottavaa lähtökohtaa. Tilanne on erikoinen, kun ajatellaan, miten keskeinen yksikkö runokokoelma on modernistiselle lyriikalle. Modernistinen runous hyödyntää usein sarjallisuutta, samoin kuin se prosessoi runojen välisiä vastakohta-asetelmia ja muita yksittäistä runoa laajempia rakenteita luodakseen kuvan modernin ihmisen jännitteisestä olemuksesta ja maailmankatsomuksellisesta kamppailusta.

Södergran-tutkimus on ollut 1980-luvulle saakka historiallisbiografista, kirjailijakeskeistä ${ }^{3}$ tutkimusta. 1980-luvulta on alkanut tutkimuksen uudelleenarviointi ja Södergranin tuotannon lukeminen teksti- ja kontekstikeskeisen kirjallisuusteorian valossa. Valtaosaa Södergran-tutkimuksesta voi luonnehtia temaattiseksi. Temaattisuus merkitsee laajojen yleislinjojen piirtämistä kulloisenkin erityiskysymyksen taustaksi, olipa kyse sitten Södergranin tuotannon tarkastelusta sisältä käsin esimerkiksi apokalypsin, arkkityyppien tai luomistematiikan valossa (Hedberg 199I; Evers 1992) tai tuotannon kytkeminen aikansa kirjallisiin

\footnotetext{
' Analyyseissa Framtidens skugga lyhennetään muotoon FS. Runositaattien sivunumerot viittaavat Södergranin runojen kriittiseen laitokseen Dikter och aforismer. Samlade skrifter I (Södergran 1990).

${ }^{2}$ Laajimpia tutkimuksia runon ja kokoelman suhteista on tehnyt Neil Fraistat (1985; 1986). Uudempaa tutkimusta edustavat kokoelmamallien orgaanisuutta ja konstruktiivisuutta selvittänyt Dirk van Hulle (2006) sekä narratologisesta näkökulmasta lyyristä kokoelmaa lähestyneet Hühn \& Kiefer (20II).

3 Nykynäkökulmaista, arkistotutkimuksesta ammentavaa metaelämäkerrallista tutkimusta tekee Agneta Rahikainen (20I4).
} 
(Schoolfield 1984; Brunner 1985), aatehistoriallisiin (Lillqvist 2003; Häll 2006) tai modernismiin liittyviin yhteiskunnallisiin, sukupuolta ja minuutta koskeviin diskursseihin (Suchslands 1990; Witt-Brattström 1997; Hackman 2000; Rahikainen 20I4). Vaikka teosten kirjallisia ja rakenteellisia piirteitä on kuvailtu alusta saakka ja Södergranin tuotannon sisäiset ja intertekstuaaliset suhteet pääpiirteissään kartoitettu, ovat komposition ja kokoelmarakenteen kysymykset olleet tutkijoille toissijaisia. Tarkemmat rakenteeseen paneutuvat tutkimukset ovat keskittyneet ennen muuta Södergranin tuotannon säemuotoon (Lilja Norrlind I98I), kuvallisuuteen (Brunner 1985; Lillqvist 200I; Haapala 2003) ja myytteihin (Hedberg 1991). Lähinnä oma väitöskirjani (2005) on avannut tietä kokoelmakokonaisuuteen painottuvalle tutkimukselle, aiemmin jossakin määrin Holger Lillqvistin tutkimus (esim. 200I: 63-66).

Kokoelmakokonaisuus on tärkeä tutkimuskohde siksi, että se on modernistisen kirjoittamisen paradigma. Yhtä tärkeä se on siksi, että kokoelma on yksittäisten runojen ja tuotannon merkitysten kannalta ensimmäinen konteksti, joka asettaa kriteereitä sille, millaisia tulkintoja ja väitteitä kirjallisesta teoksesta ja sen osista voidaan perustellusti esittää. Hieman kärjistäen voidaan sanoa, että Södergran-tutkimuksen suurin ongelma on ollut sen suhde perustaan: runoilijan teoksia ei ole luettu tarkasti kokonaisuuksina, vaan tutkimus on tehnyt tulkintoja paljon summittaisemmista temaattisista tai ideologisista lähtökohdista käsin. Voimakkaasti tuotannon ulkoisia konteksteja painottavia tutkimuksia voi kutsua spekulatiivisiksi. Ne keräävät tarkastelun kohteiksi juuri ne runot, joita tarvitsevat saadakseen mieleisensä tulokset. Voimakkaimmin tämä näkyy joissakin feministisissä lähtökohdissa: tutkimuksellisten analogioiden tarkoitus on toki ollut tuoda klassikkoteksteistä esiin uusia piirteitä mutta yhtä lailla rakentaa tutkijan maailmankatsomuksellista positiota. ${ }^{4}$ Kun kiinnekohdaksi valitaan kokoelman rakenteista paljastuva maailma ja siinä jäsentyvät puhujasuhteet tai kuvalliset ja rytmiset ratkaisut, vältytään summittaisuuden vaaralta, joka uhkaa tuotannon ulkoisia konteksteja ja voimakkaasti tutkimusparadigmaa painottavaa lähestymistapaa.

Koska en voi yhden artikkelin mitassa käydä erityisen laajaa keskustelua siitä, miten kokoelmakokonaisuuden rakenteellinen kuvaus ja tulkinta kohtaavat aiemmat temaattiset tulkinnat, olen valinnut esimerkinomaiseksi keskustelukumppaniksi Torsten Petterssonin (200I) hedelmällisen ja tähänastista Södergran-tutkimusta radikaaleimmin haastavan ajatuksen itseironiasta mallina, joka jännittää Södergranin tapaa hahmottaa teoksiaan.

Pettersson tutkii teoksessaan Gåtans namn (200I) yhdeksää suomenruotsalaista modernistia, joiden tuotannosta hän nostaa esiin keskeisiä aatteellisia ja emotionaalisia peruskuvioita. Södergranin kohdalla Pettersson pyrkii kyseenalaistamaan mallinnusta, joka on hallinnut Södergranin tuotannosta tehtyä tutkimusta. Tideströmistä (1949) alkaen

${ }^{4}$ Kaikkein spekulatiivisin on Ebba Witt-Brattströmin monografia Ediths jag (1997). WittBrattström rakentaa konteksteja tuotannosta irralleen poimittujen runojen ympärille ja identifioi Södergranin tulkinnallisten analogioiden avulla useisiin aikalaiskonteksteihin. "Som om" -metodilla Södergranista tulee muiden muassa uusi nainen, venäläinen naisrunoilija, nietzscheläinen strategi ja modernismin messias. 
Södergranin tuotanto on jaettu kolmeen tyylilliseen ja aatteelliseen periodiin. Ensimmäiseen kuuluu Södergranin esikoisteoksen Dikter (1916) impressionistinen ja symbolistinen tyyli, jota hallitsee temaattisesti luonto- ja rakkauslyriikka. Ensimmäiseen periodiin kuuluvat myös ne Septemberlyran -kokoelman (1918) runot, jotka on päivätty vuosille 1916 ja 1917. Samaan kauteen lasketaan postuumisti julkaistun Landet som icke är -kokoelman (1925) ensimmäisen osaston runot. Toinen periodi on ekspressionistinen maailmanparannuksen vaihe, jota leimaa vaikuttuminen Friedrich Nietzschen filosofiasta. Kausi kattaa kokoelmat Septemberlyran, Rosenaltaret (1919) ja Framtidens skugga (1920) sekä kaksi keskimmäistä osastoa kokoelmasta Landet som icke är. Tässä periodissa korostuu luomisproblematiikka ja metapoeettisuus sekä pyrkimys nietzscheläiseen arvokritiikkiin. Kolmas periodi muodostuu kymmenestä runosta, jotka Södergran kirjoitti viimeisenä vuotenaan. $\mathrm{Ne}$ muodostavat Landet som icke är -kokoelman neljännen osaston. (Tideström 1949: 400-402; Hedberg 1991: 27-28; Evers 1992: 16; Pettersson 200I: 27.) Vaikka periodisoinnin rajanvedoista ja sisällöistä on keskusteltu toistuvasti kolmen viime vuosikymmenen aikana (ks. esim. Jones \& Branch 1992; Broomans et al. 1993; Lillqvist 2003; Haapala 2005), Petterssonin tulkinta valottaa Södergranin tuotantoa uudesta näkökulmasta. Hänen mukaansa tuotantoa luonnehtii kauttaaltaan katsomuksellinen kahtalaisuus:

\footnotetext{
$\AA$ ena sidan gestaltar hon en åskådning - och ofta med stor kraft - men å andra sidan undergräver hon den genom en självironisk hållning, som kan få åskådningen att framstå som en medvetet konstruerad tankelek (Pettersson 200I: 27).
}

Pettersson ei siis ajattele, että runoilija siirtyisi syvästi omaksutusta aatteellisesta painopisteestä ja periodista toiseen, vaan että Södergranin tuotannossa olisi jatkuvasti kyse tietoisesta leikistä erilaisilla katsomuksilla. Petterssonin ajatus Södergranista erilaisten maailmankatsomuksellisten roolien kirjoittajana ja kyseenalaistajana on innostava tulkinnallinen avaus. Kuitenkaan näkemys Södergranin itseironiasta ja tietoisesti konstruoiduista ajatusleikeistä ei tunnu täysin luontevalta, kun tarkastellaan Södergranin kokoelmia kokonaisuuksina. Tarkoitukseni on haastaa ja täsmentää Petterssonin tulkintaa paneutumalla Södergranin kuuluisaan kokoelmaan Framtidens skugga, josta Pettersson nostaa Södergrania koskevan tutkimuksensa otsikon "Lekarnas lek". ${ }^{5}$

Pettersson käy monografiansa yhdessä luvussa läpi Södergranin runoteokset. Siksi hänen analyysinsa Framtidens skugga -kokoelmasta jää pakostakin yleisluontoiseksi (200I: 52-56). Hän kohdistaa huomionsa 17 runoon, eikä runojen yksityiskohdissa viivytä pitkään. Pettersson kommentoi ensimmäisestä ja toisesta osastosta kummastakin kuutta runoa ja kolmannesta osastosta viittä runoa. Itse analysoin kokoelman puhujarakenteen jäsentymistä runo runolta edeten. Näin voin vastata perusteellisesti Petterssonin ajatukseen itseironian säätelemästä tietoises-

\footnotetext{
${ }^{5}$ Petterssonin esitystä ei ole haastettu ennen omaa väitöskirjaani, jossa polemisoin Petterssonin tulkintaa etenkin Södergranin ensimmäisen kokoelman osalta (ks. Haapala 2005: 44I-446).
} 
ta ajatusleikistä ja esittää oman tulkintani. Kuljetan Petterssonin tulkintaa omani rinnalla ja teen lisäyksiä, jotka osoittavat, että Petterssonin väite itseironisesta leikistä on vain osittain oikeutettu. Näkökulmani on ennen kaikkea runojen puhujien asemassa, puhujien edustamissa katsomuksissa sekä runojen ja osastojen välisissä suhteissa.

Oma analyysini sekä haastaa Petterssonin idean että myös tarkentaa näkemystä Södergranin tuotannon kolmesta vaiheesta. Osoitan, että tarkka kokoelmakomposition analyysi kykenee kuvaamaan kirjallista tuotantoa ja haastamaan tulkintoja. Näkökulma ei ole pelkästään rakenteellinen. Se antaa hyvät lähtökohdat arvioida, miten Södergranin runokieli toimii temaattisesti ja ideologisesti. Se tarjoaa temaattiselle tutkimukselle tilaisuuden tarkastella tuloksiaan. Menetelmän varjopuolena on, että yleisluonteisessa kuvauksessa en voi kovin yksityiskohtaisesti paneutua kokoelman yksittäisiin runoihin ja niiden monimerkityksisyyteen.

Miksi sitten lähden liikkeelle kokoelmakokonaisuuden kartoituksessa puhujien tarkastelusta? Lähtökohta on hedelmällinen siksi, että puhujat ja eri tavoin roolitetut puheaktit tuovat selkeästi esiin kokoelman maailmaa määrittäviä suuria teemoja, kuten tulevaisuutta, valtaa, tahtoa, kuolemaa, ruumiillisuutta, totuutta ja kohtaloa sekä niihin liittyviä näkökulmia. Temaattiset avainsanat asettuvat Framtidens skugga -kokoelman jokaisen osaston puheaktien horisontiksi eli runojen puhujat asemoivat itseään suhteessa niihin. Keskittyminen puhujarakenteisiin on nähdäkseni taloudellisin keino saada ote siitä, miten teoksen runot kuljettavat samoja teemoja eri suuntiin. Tällä tasolla on mahdollista ottaa kantaa myös Petterssonin esiin nostamaan katsomukselliseen leikkiin.

Analysoidessani puhujia käytän samanlaisia työkaluja kuin väitöskirjassani, jossa tutkin Södergranin esikoisteoksen Dikter (1916) yksittäisten runojen puhujien ryhmittymistä laajemmiksi puhuja-asemiksi (Haapala 2005: 86-92; Haapala 201 I: 57-78). Loin puhuja-aseman käsitteen heterogeenisten, puhujiltaan vaihtelevien runoteosten analyysia varten. Södergranin Framtidens skugga ei sisällä ilmiselvästi yhtä ja ainoaa, läpi teoksen samana pysyvää puhujaa, vaan koko joukon vaihtuvia puhujia tai ainakin rooleja, joita kokonaisuus säätelee. Kokoelman hahmottamiseksi on näin ollen syytä katsoa, miten eri runojen puhujat asettuvat suhteessa toisiinsa. Puhuja-asemalla tarkoitan sitä, että itsenäisten runojen puhujat jakavat samankaltaisia arvoja, kokemuksia, valintoja ja suhtautumistapoja. Puhuja-asemat, jotka implikoivat käsitystä minuuden ja todellisuuden suhteista, syntyvät toisiaan lähellä olevista retorisista asemoinneista. Puhuja-aseman käsite korostaa myös runojen sanaston ja kuvien organisoitumisen välisiä yhtäläisyyksiä (Haapala 2005: 91). ${ }^{6}$ Puhujuuden analyysiin lisäksi ja sen rinnalla erittelen teoksen osastojen sekä runojen välisiä jatkuvuuksia ja vastakohtaisuuksia.

Puhujakysymyksen jäsentämä, teksti- ja teoskokonaisuuslähtöinen otteeni tarjoaa aiempaa nyansoidumman kuvan sekä kokoelmarakenteen jännitteisyydestä että teoksen sijoittumisesta Södergranin tuotantoon.

${ }^{6}$ Tarkemmin puhujuutta koskevista käsitteistäni ks. Haapala 2005: 77-94; 20 I I: 64-74. Otan tässä analyysissa käyttöön vain puhuja-aseman käsitteen. 
Lähtökohtani tuo olennaisia tarkennuksia myös Petterssonin väitteisiin runon puhujasta. Petterssonin muutoin Södergran-tutkimusta haastava lähestymistapa ei erottele tarkasti runokokoelman sisäisiä puhetasoja ja runoilijaa toisistaan, vaan puhuu yleiskäsittein, etupäässä analyysien esseistisen tyylivalinnan vuoksi. ${ }^{7}$

\section{Framtidens skugga -kokoelman yleispiirteitä}

Framtidens skugga (1920) on viimeinen kokoelma, jonka Edith Södergran ehti viimeistellä elinaikanaan. Teos on monella tapaa hätkähdyttävä: kuoleman, taiteen, elämänvoiman ja totuuden kysymykset kietoutuvat toisiinsa. Teos muodostaa tuotannon murtumapisteen. Yhtälälä siinä näkyvät aiemmasta tuotannosta tutut nietzscheläisittäin värittyneet utopiat taiteen tulevaisuudesta, toisaalta siinä on näille vieras, henkilökohtaisempi juonne: kirjoittamisen merkityksen pohdinta sekä yritys sovittaa elämänhalun ja kuolemantietoisuuden jännitteet. ${ }^{8}$ Kirjallisuudentutkijalle kokoelma tarjoaa ennen kaikkea kiinnostavan mahdollisuuden pohtia edellä mainittujen elementtien jäsentymistä kokoelmakokonaisuudessa.

Framtidens skugga on jaettu kolmeen osastoon: Planeterna stiga, Framtidens skugga ja Älvdrottningens spira och andra dikter. Ensimmäisessä, kosmisiin sankarinäkyihin keskittyvässä osastossa on yhdeksän runoa, toisessa, elämän ja kuoleman jännitteeseen paneutuvassa osastossa kymmenen runoa ja viimeisessä, edellisten teemojen lisäksi kirjoittamisen merkitystä ja totuutta reflektoivassa osastossa kaksikymmentäkaksi.

Runotyypeiltään ja -muodoiltaan teos ei tuo mitään uutta Södergranin aiempiin kokoelmiin: se koostuu pääosin vapaarytmisistä runoista. Osa runoista on keskeislyyristä metalyriikkaa, osa roolirunoja tai sille läheisiä runomuotoja. Tyylillisesti teos on melko yhtenäinen. Tyypillisin runo on yhdestä säkeistökokonaisuudesta koostuva lyyrinen runo, joka hallitsee Södergranin tuotantoa yleensäkin. Paikoin yhden säkeistökokonaisuuden runoa murretaan typografisesti katkosta ilmaisevilla fragmenttimerkinnöillä - tällöin kyse on joko runon puhujan epäröinnistä, asennoitumisen muutoksesta tai ekstaasista. Eniten fragmentoituvia runoja on kolmannessa osastossa ("Älvdrottningens spira", "O du mitt hjärtas vidd...", "Extas" ja "Fyra små dikter"). Ensimmäisessä ja toisessa osastossa fragmentoituvia runoja on yksi kummassakin, "En gammal härskare" ja "Eros tempel". Teoksen etenemisen myötä lisääntyvän fragmentoitumisen voi tulkita kuvaavan runojen intensiteetin kasvua ja puhujien voimistuvaa kokemusta. Yhden säkeistökokonaisuuden runotyypistä poiketaan vain runoissa "Skaparegestalter", "Solen",

\footnotetext{
7 Petterssonin ilmaisu "hon gestaltar en åskådning" viittaa Södergraniin runojen asenteen hahmottajana. Runotasolla ilmaisuja ovat "jagperson" ja "hennes individuella situation", jotka identifioivat puhujan naiseksi (Pettersson 200I: 54). Puhujan sukupuoli ei ole kaikissa kokoelman runoissa itsestäänselvyys.

8 Toki henkilökohtaisia ja metalyyrisiä runojaksoja on Södergranin aiemmissakin kokoelmissa, mutta vakava runouden luonteen kysyminen, samoin kuin elämänhalun ja kuolemantietoisuuden jännite ovat uusia aihepiirejä.
} 
"Nätet" ja "Framtidens skugga", joissa kussakin on kaksi säkeistöä, sekä runoissa "Vattenfallet", "Vid soluppgång" ja "Stjärnan", jotka ovat kolmisäkeistöisiä ja kuvaavat tärkeitä valintoja ja voimakasta kohtalotietoisuutta.

Laajuudeltaan kahta ensimmäistä osastoa vastaavassa kolmannessa osastossa on tekstien sarjallista ryhmittelyä perättäisissä runoissa "Hyancinten" (I-II) ja "Fyra små dikter" (I-IV). Osaston nimiruno on pitkä katkelmallinen rooliruno, joka muistuttaa rakenteeltaan Septemberlyran -kokoelman (1918) päätösrunoa "Fragment" ja jatkaa Södergranille tyypillisten satuintertekstien hyödyntämistä.

Runomuotojen odotuksenmukaisuudesta huolimatta kokoelman kokonaisjäsennys ja etenkin puhujien vaihtuvat roolit ovat tarkastelun arvoisia. Juuri puhujuudessa syntyy murros suhteessa Södergranin kahteen aiempaan, nietzscheläisyyden innoittamaan teokseen.

\section{Planeterna stiga: tulevaisuuden uhoa ja epäilyä}

Ensimmäinen osasto Planeterna stiga koostuu pääasiassa kosmisista voimantunnon runoista, jotka ovat tuttuja Södergranin kokoelmista Septemberlyran (1918) ja Rosenaltaret (1919). Kuvastossa toistuvat planeetat, tähdet ja aurinko. Runojen puhujat tarkkailevat avaruuden ilmiöitä ja rinnastavat oman toimintansa ja odotuksensa niihin. Kuten osaston nimi antaa ymmärtää, kyse on nousevien ja vaeltavien tähtien kuvaamisesta. Taivaankappaleet vertautuvat luoviin tulevaisuuden ihmisiin. Runojen kuvasto on sotaisaa ja aggressiivista. ${ }^{9}$ Runojen puhujat ovat voimakkaita poikkeusyksilöitä, jotka kokevat päämääräkseen muovata elämää.

Puhujien ja puhetilanteiden määrittymisen kannalta osaston runot ovat abstrakteja. Yhdenkään runon puheaktia ei ole helppo sijoittaa konkreettiseen tilanteeseen. Pikemminkin kyseessä on joukko kirjallisia ääniä, jotka puhuvat taiteen ja muun henkisen elämän tulevaisuudesta profeetallisin äänenpainoin. Osasto on ylevän kokemuksen runollista hahmottelua, jossa retoriset puhuttelut ja puoleen kääntymiset niveltyvät osaksi uhoavaa itsemäärittelyä. Kokoelman nimessä esiintyvä kuva "tulevaisuuden varjosta" näyttäytyy aavistuksena tulossa olevasta luomisen tilasta, jonka toteutumista odotetaan ja vahvistetaan.

Osaston kolme ensimmäistä runoa jakavat saman retorisen puhujaaseman eli ne luovat kuvan voittajasta, poikkeusyksilöstä. Avausrunon "Mysteriet" puhuja eroaa "muista ihmisistä" ja "eilisestä". Puhuja, "tämän päivän" ihminen, lupaa muuttaa koko ihmiskunnan taivaasta saamansa miekan avulla: "O du mitt goda svärd, som jag har fått / från himlen,

\footnotetext{
9 En voi paneutua kunnolla kokoelman intertekstuaalisiin ulottuvuuksiin, mutta mytologinen kuvasto hyödyntää voimakkaasti kirjallista perinnettä. Planeettojen sotaisuus ja tuhovoima viittaavat Marsiin, sodan jumalaan. Marsin tuhovoima muunnetaan kokoelmassa luovien yksilöiden voimaksi ("Fientliga stjärnor", "Skaparegestalter"). Runoilijan symbolina esiintyy kotka, joka edustaa mytologioissa Jupiteria (tai Zeusta), taivaan ja sen ilmiöiden jumalaa ("Beslut", "Blixtens trängtan"). Mytologisista jumaluuksista vain Eros mainitaan suoraan. Sekin on modernisti tulkittu vallantahdon henkilöitymä. Södergranin tapa käyttää mytologisia hahmoja tulee lähelle nietzscheläistä allegoriaa (ks. Haapala 2005: 403-405).
} 
jag kysser dig. / Du skall vila / innan jorden är en trädgård, där gudarna drömma / vid underbara bägare." (FS, I35.) Toisessa runossa "Tolerans" poikkeusyksilö on "omaa lakiaan noudattava", hänen kätensä "tahtoo sortaa maahan sen mitä toiset pönkittävät". Hän on "voittaja" ja "alistaja", kuten runon puhuja määrittelee tähtien leikistä syntyvää hahmoa. Kolmannen runon "Makt" puhuja vahvistaa luodun aseman: "Jag är den befallande styrkan. [...] Jag följer ingen lag. Jag är lag i mig själv. / Jag är människan som tager.” (FS, 136.) Runon puhuja jatkaa ensimmäisen runon puhujan profeetallista asemaa kutsuessaan seuraajia: "Var finnas de som följa mig?" Kysymyksen voi lukea itsekorostuksena, mutta siinä näkyy liki koko osastoon ulottuvan retorisen puhuja-aseman luominen: poikkeusyksilö määrittelee ensin omat ominaisuutensa kosmisella kuvastolla ja kutsuu sitten muita kaltaisiaan.

Kolmen ensimmäisen runon puhujaa on luontevaa ajatella yhtenä ja samana. Runoissa todentuu poikkeusyksilön asenne ja puheen tapa on yhtenäinen. Runot luovat vaihe vaiheelta (mysteerio, valta, toleranssi) vahvan puhujan aseman ja erilaisin puhutteluin kutsun sellaisena olemiseen. Ne myös muodostavat teoksen eksposition: esittelevät runojen maailman, sille keskeisen puhujatyypin ja kuvaston sekä puhujille keskeiset eleet ja tavoitteet (ks. Haapala 2012: 165-167; Phelan 2008). ${ }^{10}$

Neljäs runo "En gammal härskare" tuo asennonvaihdon suhteessa kolmen ensimmäisen runon sekvenssiin. "En gammal härskare" on jo nimensä mukaan rooliruno, toisin kuin aiemmat runot, joiden otsikossa puhujaa ei määritetä tarkasti. Otsikko osoittaa, että runossa puhuu vanha valtias. Runon puhuja on rakentanut linnan valloittajille. Puhuja kääntyy ensin maan, sitten tulevaisuutta edustavien nuorten poikkeusyksilöiden puoleen":

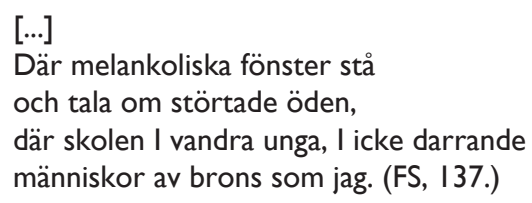

Runo on edennyt samaan tapaan kuin osaston aiemmat runot, vanhan ja uuden vastakohtaa vahvistaen, lupauksena tulevaisuudesta. Puhuja on todennut, että nuoret ovat samaa pronssia kuin hän. Seuraavassa säkeessä sävy yllättäen muuttuu:

\footnotetext{
10 Olen tutkinut artikkelissani "Teoskokonaisuuden poetiikkaa" (20I2) runo-osastojen aloituksia ja kehystystä sekä osastojen muodostamia väitteitä. Aloitusta tai ekspositiota on tarkasteltu runsaasti myös narratologiassa. James Phelanin määrittelyssä kertomuksen ekspositio sisältää paratekstit sekä johdatuksen teoksen henkilöihin, miljööseen ja tapahtumiin. Ekspositioon lukeutuu myös taustan valaiseminen. (Phelan 2008: 197-198; ks. myös Richardson 2008.) Varsinkin pitkiä kertovia lyyrisiä runoja sekä muodoltaan ja temaattiselta jäsennykseltään tiukkaa formulaa noudattavia lajeja, kuten sonettia, on luettu narratologisen käsitteistön avulla (ks. Hühn \& Kiefer 20I I). Vaikka lyriikantutkimuksen asetelmia on usein hyödyllistä valaista narratologisella käsitteistöllä, ei esimerkiksi Framtidens skugga muodosta sellaista kertovaa kokonaisuutta, jossa narratologinen lähestymistapa olisi omimmillaan.

"Runossa on monia viitteitä Södergranin aiempaan tuotantoon, etenkin Septemberlyran -kokoelman (1918) päättävään runoon "Fragment", joka kuvaa nietzscheläisittäin luojahahmojen tulevaisuutta ja jossa vuorten ja myrskyn kaltaiset ihmiset kulkevat läpi pysähtyneen maailman.
} 


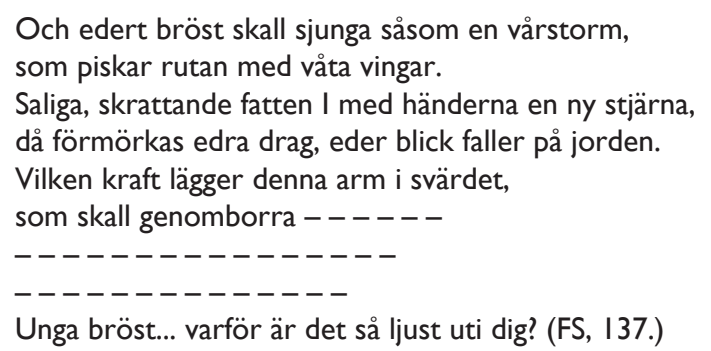

Tulevaisuuden hahmojen tarttuessa tähteensä heidän naurunsa vaihtuu synkkyydeksi ja katse painuu, ikään kuin tähti toisi mukanaan jotain synkkää ja väkivaltaista. Puhuja tajuaa voiman, jolla nuoret kamppailuun ryhtyvät, mutta silti murtava voima jää päämäärättömäksi. Epäröintiä ja kenties myös väkivaltaa merkitään kahden ja puolen säkeen mittaisella typografisella katkoksella. Lopun kysymys on jopa pessimistinen ja kyseenalaistava: "Unga bröst... varför är det så ljust uti dig?" On kuin puhuja tahtoisi sanoa, ettei voimanponnistuksesta seuraa välttämättä mitään hyvää.

Miksi vanha valtias puhuttelee "kevätmyrskyn lailla laulavia rintoja" eli runossa aiemmin puhuteltuja voittajahahmoja näin? Miksi hallitsija ei enää ylistä heitä, vaan pikemminkin kysyy näkemäänsä epäillen valoisuuden syytä. "En gammal härskare" -runon myötä kokoelmaan syntyy ristiriita: ehkä tulevaisuus ei ole aivan valoisa. Tulevaisuuden valoon lankeaa ensimmäinen varjo. Runon fragmentoituva typografinen muoto korostaa, että voimantunto vaihtuu epäilykseen, jopa hajoamiseen.

Osaston viides runo "Fientliga stjärnor" jatkaa neljännen kriittistä ääntä. Sen voi tulkita muodostavan edeltäjänsä kanssa runoparin ja uuden puhuja-aseman, joka haastaa kolmen ensimmäisen runon uskoa tulevaan. Uusien yksilöiden symbolina esiintyneet tähdet saavat kielteisen merkityksen:

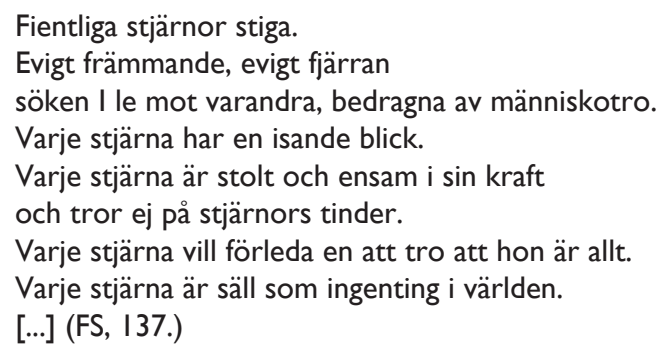

Katalogirunon puhuja ei paikannu pronominaalisesti, mutta selvää on, että hän ei ole yksi tähdistä, poikkeusyksilöistä. Osaston alun runojen jakama puhuja-asema eli voitokkaiden kosmologinen voimantunto ironisoituu. Puhujan mukaan voimakkaiden yhteisöllisyys on katteeton unelma, jota luonnehtii teennäisyys ja vieraus. Hän syyttää tähtiä solipsismista ja hybriksestä. Puhujan tuomio on, että tähtien halusta seuraa maailmanpalo, tuho ja vallankäyttö: "Varje stjärna vill sätta världen i brand med sin blossande / rand. / Varje stjärna kommer tågande som ett rött sken ur / fjärran / för att förstöra, äta upp, förbränna, utöva sin makt.” (FS, I37.)

Juuri puhujan kriittinen asenne yhdistää sen neljännen runon vanhaan hallitsijan asenteeseen. Tässäkin tapauksessa puhujat voi 
tulkita yhdeksi ja samaksi. Molemmissa runoissa puhe on kuitenkin monimielistä. "Fientliga stjärnor" -runon puhuja kritisoi tähtiä, mutta antaa arvostelulle erityisen ehdon kuvatessaan tähtiä määreellä "bedragna av människotro". Onko "tähdissä" kyse samoista yksilöistä kuin kokoelman alussa, vai näennäisesti luovista yksilöistä, jotka "yrittävät hymyillä toisilleen"? Tarkkaa vastausta on mahdoton antaa, mutta epäilyksen siemen tulevaisuuden mahdollisuuksia kohtaan on kylvetty. Petterssonin analyysi jättää kokonaan huomiotta kuvaamani jännitteen kahden puhuja-aseman välillä, vaikka hän keskittyy hetkeksi pohtimaan "Fientliga stjärnor" -runon puhujaa ja tämän epäröintiä kosmisen näyn edessä (Pettersson 200I: 53).

Näiden kahden, osastoon jännitettä tuovan asemoinnin jälkeen palataan kuudennessa runossa "Skaparegestalter" jälleen voittajan puheentapaan. Runon puhujalla on "rautasydän", joka "pakottaa ihmisten merta", muovaa "ihmisten valtavaa massaa" "iloksi jumalille". Runo on antiteesi kahden edellisen runon asenteelle, mutta toisaalta se vahvistaa hyvinkin täsmällisesti "Fientliga stjärnor" -runon kriittisen kuvan tähtien ylimielisyydestä. Näin kuudes runo voimistaa osaston dialektiset suhteet. Luojahahmot tulevat ivallisina kaukaisuudesta, juuri niin kuin edellisessä runossa on kuvattu: "Vaggande i lösa sadlar komma vi / de okända, lättsinniga, starka. / Bär oss vinden fram? / Såsom ett hånskratt klinga våra röster ur fjärran, / fjärran..." (FS, I38.)

Osaston seitsemännen runon "Wallensteinprofil" otsikko viittaa Friedrich Schillerin Wallenstein -näytelmätrilogiaan (I798-1799), jonka päähenkilö on kenraali Albrecht von Wallenstein. Schillerin draamat seuraavat kenraalin sodankäyntiä, häneen kohdistuvia valtajuonitteluja ja hänen traagista kuolemaansa. Södergranin runo on metalyyrinen muotokuva ("profil"), joka kuvaa pahojen voimien kohtaamista. Kyseessä ei ole pahuuden vastustaminen vaan sen kanssa liittoutuminen:

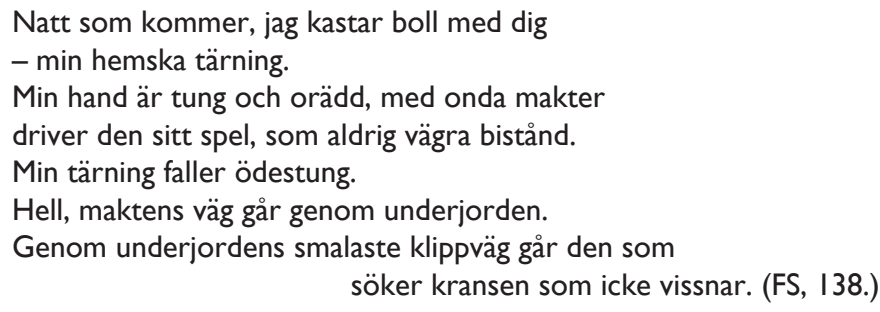

Vaikka "Wallensteinprofil" on teoksen ensimmäinen varsinainen metalyyrinen runo, siinä ei kuvata niinkään konkreettista kirjoitustyötä kuin niitä ehtoja, joiden vallitessa kuolematon taide syntyy. Runon puhujan mukaan luominen vaatii vastavoimia, jotta päästään vallan tielle. Puhuja tervehtii pahan voimia ja uskoo, että tie kuolemattomuuteen vaatii kulkemista manalassa.

Runo asettaa luomisen ehdoksi dialektisen vastakohdan. Puhuja edustaa osaston alun poikkeusyksilöiden muodostamaa puhuja-asemaa, mutta runossa myönnetään ensi kertaa, että nopanheitto tulevaisuudesta merkitsee vaaraa myös puhujalle, poikkeusyksilölle. Vasta myöhemmin, kolmannen osaston runossa "Hamlet", nämä ajatukset syvenevät ristiriidoiksi ja kysymykseksi tulevaisuuskuvitelmien kestävyydestä ja totuudesta. Runossa keskeisintä on sankarillinen affirmaatio ja kyky selviytyä kuiluista. 
Kaksi seuraavaa runoa, jotka päättävät osaston, vievät manalasta takaisin kosmisiin näkyihin. "Stjärnorna vimla" ja "Planeterna" muodostavat neljännen ja viidennen runon tapaan parin. Asenteeltaan osaston kolmeen ensimmäiseen runoon rinnastuvat runot kuvaavat luomisen ekstaasia ja uuden ajan odotusta. Ne tuovat toiminnan ja tahdon rinnalle tunteen: "mielettömyys", "uusi kaipuu" ja "suuri onni" saavat ihmiset unohtamaan kaiken maallisen. Planeettojen tuloon liittyy "autuus". "Stjärnorna vimla" on kuvaus siitä, miten uusia aika muuttaa ihmiset. "Planeterna" -runossa luovien yksilöiden saapuminen nähdään ainoana mahdollisuutena, vain heidän tulevaisuutensa on viitoitettu: "Snabbare, raskare, obarmhärtigare, vältrande sig / i underbara öden, / rullar planeternas oräkneliga skara förbi / mot ett ljust sken i väster - / möjlighetens enda utstakade väg” (FS, I39.)

Ensimmäisen osaston jälkeen voidaan kysyä, mikä merkitys tällaiseen järjestykseen asemoidulla ja eri suuntiin vetävien puhujien retorisella asemoinnilla on. Torsten Pettersson (200I: 53) esittää seuraavan yhteenvedon: "Som helhet bygger denna avdelning sålunda ut det krön av självsäker förkunnelse som etablerades i Rosenaltaret." Vastaus ei ole näin yksinkertainen. Varmaa on, että osasto asettaa vastakkain luovat poikkeusyksilöt ja tavalliset inmiset, joilla ei ole edes ääntä. Jännitteisempi vastakkainasettelu vallitsee kuitenkin valloittajien eli luovien, nuorten yksilöiden (runot I-3 sekä 6-9) sekä vanhan hallitsijan ja kriittisesti luomiseen suhtautuvan tähtien epäilijän välillä (4-5). Mikäli osastoa tulkitaan Petterssonin perusidean tapaan itseironisena roolileikkinä - tulkinta, jota Pettersson ei itse tee, vaan näkee osaston yksiäänisenä - voidaan todeta, että osasto kuvaa, kuinka usko taiteen tulevaisuuteen voi osoittautua yhtä hyvin katteettomaksi uhoksi kuin lunastettavissa olevaksi mahdollisuudeksi.

Yhtä lailla voidaan myös tulkita, että epäuskoisesti tulevaisuuteen suhteutuvat äänet edustavat pessimismiä ja väsynyttä, vanhaa maailmaa. Asenteen puhemies on "vanhan hallitsijan" roolihahmo. Tällöin pessimismiä ja kritiikkiä edustavat runot 4 ja 5 eivät muodostaisi varsinaista kumoavaa vastaääntä vaan ideologisen taustan, joka voittajahahmojen kontrastiksi on osastoon kirjoitettu. Joka tapauksessa melko abstraktiksi jäävä ensimmäinen osasto antaa suuntaa seuraaville osastoille: tulevaisuus on luovien, mutta tulevaisuuden toteutuminen ei ole täysin varmaa.

\section{Framtidens skugga: henkilökohtaiset runot ja kamppailu kuolemaa vastaan}

Toisen osaston Framtidens skugga myötä kokoelmaan avautuu aivan toisenlainen maailma. Ihmiskunnalle runoillun tulevaisuuden ja erilaisten suhtautumistapojen abstrakti hahmottelu saa rinnalleen henkilökohtaisemmat säkeet elämästä ja sen rajoista. Henkilökohtaisuus tulee tässä ymmärtää suhteessa ensimmäisen osaston luonnoksiin tulevaisuudesta: nyt kyse on runoista, jotka ilmentävät keskeislyyristä, konkreettisia asioita ja tunnetiloja ilmaisevaa puhujaa, vaikka ensimmäisen osaston teemat jatkuvat tämän puhujan puheakteissa. 
Kun ensimmäisessä osastossa muodostui kaksi toisistaan asenteeltaan eroavaa retorista puhuja-asemaa, toisen osaston runojen puhuja on ensimmäistä osastoa helpompi mieltää kokonaisuudessaan yhdeksi ja samaksi. Myös temaattinen painotus vaihtuu: kosmosta syleilevä uuden ja vanhan välinen jännite vaihtuu puhujan sisäiseksi kamppailuksi. Tässä kamppailussa elämää ja jatkuvuutta edustaa Eros eli luomisen, elämänvoiman ja vallantahdon personifikaatio. Sen vastakohta on elämän päättyminen kuolemaan. Voimien kohtaamispaikka on puhujan ruumis ja tajunta. Torsten Pettersson ei omassa tulkinnassaan kiinnitä huomiota tällaisiin puhujuudessa osastoittain tapahtuviin muutoksiin.

Henkilökohtaisen tason mukaan tuominen saa toisen osaston vaikuttamaan kokoelmakokonaisuudessa vaiheelta, joka kohdentuu ensimmäistä osastoa intiimimpiin ongelmiin, mutta myös valmistelee kolmatta osastoa, jossa edeltävät pyrkimykset kohtaavat ja joutuvat törmäyskurssille. Toisen osaston puhujan keskeinen tavoite on sublimoida oma kuolevaisuutensa ja ruumiillisuutensa siten, että kuolemassa olisi läsnä täyttymys ja autuus, ekstaasi. Avausrunon "Framtidens skugga" puhuja toteaa:

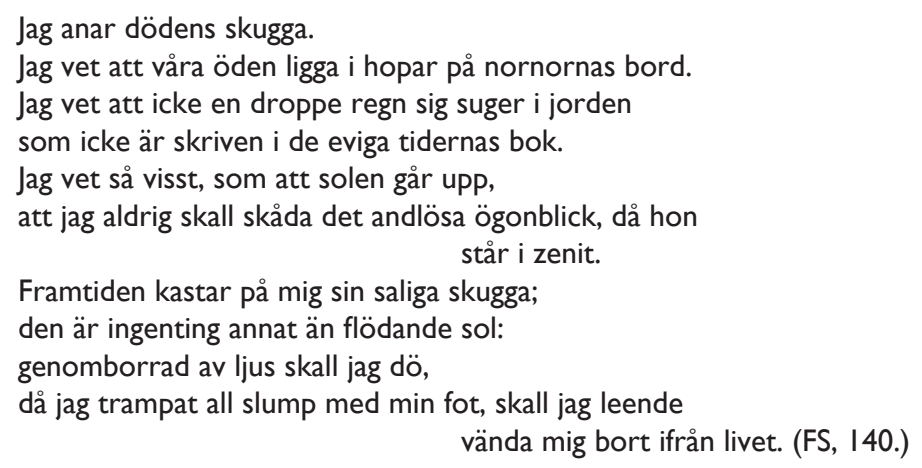

Avausruno on kuin uusi ekspositio kokoelman sisällä. Sublimaatiosta huolimatta runossa "tulevaisuuden varjon" kuvaan yhdistyy ensi kertaa kuoleman varjo, joka on puhujan kannalta lähempänä kuin runollisen tulevaisuuden muuttuminen todellisuudeksi. Syntyy uusi suunnanmääritys, joka tarkentaa ensimmäisen osaston tulevaisuuden merkitystä. Puhuja uskoo yhä runoiltuun tulevaisuuteen, vaikka tietääkin, ettei tule koskaan itse näkemään sen kirkkainta hetkeä. Pettersson tulkitsee runoa samansuuntaisesti: "Jagpersonen tror fortfarande på sitt historiska uppdrag men bereder sig på att själv lämna scenen innan den nya världsordningen inträder" (200I: 54). Puhuja tekee omalta osaltaan minkä voi: valmistaa elämästään taideteoksen, joka tuhoaa kaiken sattumanvaraisen.

Osaston toisessa runossa "Du store Eros" puhuja kääntyy rakkauden jumalan puoleen ja ottaa näin etäisyyttä ensimmäisen runon tilanteeseen:

Du store Eros. Du andas bröllop.

Men vad för bröllop?

Sen jorden stått, och åtrå vigt två kroppar samman,

har blixten icke nått

till människopanna.

Denna blixt slår,

denna blixt är allsmäktig,

blixten gör med människobarnen vad den vill. (FS, I40.) 
Runo jatkaa todellisuuden sublimointia uudesta näkökulmasta: kun osaston avausrunossa kohteena oli kuolema, on nyt kyseessä elämänvoima. Eros ei ole seksuaalisen rakkauden jumala. Puhujan mukaan ihmisten välinen eroottinen kaipuu on estänyt maailman alusta saakka Eroksen voiman kohtaamisen. Eros, joka puhujan mukaan "hengittää häitä", on mahdollisuuden, ei eroottisen ja fyysisen toiseen kiinnittymisen jumala. Sen kosketus on "kaikkivoipa" ja se tekee ihmiselle "mitä tahtoo". "Du store Eros" on kokoelman rakenteessa tärkeä runo, sillä se aloittaa toiseen ja kolmanteen osastoon hajautetun Eros-runojen sarjan. Runoissa puhuja kehittelee ajatusta Eroksesta uutena taiteellisena jumaluutena.

Osaston kolmannen runon "Vad är mitt hemland..." puhuja jatkaa ensimmäisessä osastossa muodostuneen poikkeusyksilön puhuja-asemaa. Runossa julistetaan puhujan henkisen todellisuuden ylivertaisuutta:

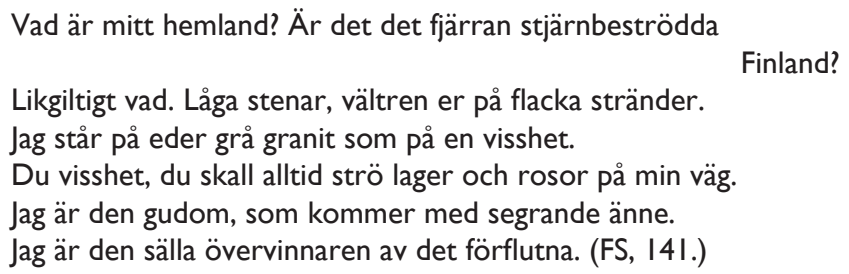

Puhujan abstraktiin jumaluusajatteluun yhdistyy paikallinen ja maantieteellinen oman paikan kysyminen ("Finland", "flacka stränder", "grå granit"). Konkreettinen paikallisuus jää tosin toissijaiseksi henkisen todellisuuden rinnalla, aivan kuten fyysinen kuolema ja eroottinen rakkaus kahdessa aiemmassa runossa.

Osaston neljäs runo "Sällhet" jatkaa avausrunon teeman eli kuoleman kohtaamisen käsittelyä. Se on kuin lähikuva "tulevaisuuden autuaasta varjosta", jota "Framtidens skugga" kuvasi. Puhuja kokee kuolevansa pian. Kuoleman syyksi annetaan autuus, tavanomaisen onnen ylittävä ilo: "Jag dör - ty jag är alltför lycklig." Runo noudattelee osastolle tyypillistä sublimaation logiikkaa: kuolinsyy ei ole ruumiin voimien hiipuminen, vaan ilon tunne, jota ruumis ei kestä. Ristiriitaa runoon tuovat groteskit kuvat käärinliinojen puremisesta ja jalkojen kouristelusta: "Av sällhet skall jag ännu bita i min svepning. / Min fot skall krama sig av sällhet i mina vita skor / och då mitt hjärta stannar - vaggas det in av vällust." (FS, I4I.) Tarkoitus on kuitenkin kuvata kuoleman kokemuksen voimakkuutta: sen autuus on nukkumista nautinnon huumaan ("vällust"), orgasmin kaltaista ilontäyteisyyttä ja hallinnan menettämistä.

Pettersson tulkitsee, että toisen osaston runojen puhujalla ("jagpersonen") on kaksi strategiaa kuolemaa vastaan: joko hän korostaa rajattomasti omia voimiaan tai nöyrtyy kuoleman edessä ja näkee sen tienä transsendenssiin (200 I: 54-55). Oman tulkintani mukaan osastossa korostuu huumaava ekstaasin ja autuuden kokemus, ei niinkään puhujan konkreettinen voima. Osaston runoista ei löydy transsendenssia, johon kuolema olisi portti. Ainoastaan osaston viimeinen, kristillinen runo tekee tähän poikkeuksen. Sen sijaan voimantunnon runot itse muodostavat jonkinlaisen kvasitranssendentaalisen tilan, joka nousee näkyvän todellisuuden yläpuolelle. 
Osaston viides, metalyyrinen runo "Tantalus, fyll din bägare" kommentoi runon kirjoittamisen prosessia ja runouden asemaa ja arvoa. Se on asenteeltaan rinnakkainen ensimmäisen osaston viidennen runon "Fientliga stjärnor" kanssa, sillä molemmat liittävät haavekuviin epäilyksen. Runossa toistettu avainsana on "omöjlighet":

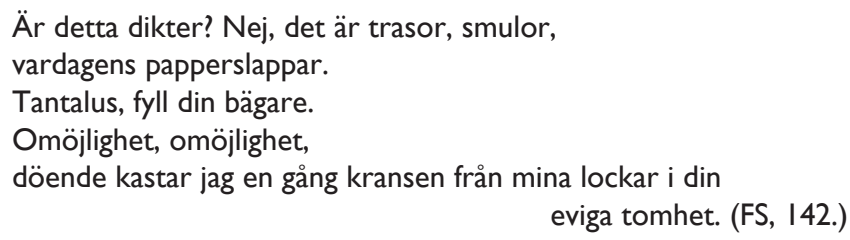

Otsikon kehotus "Tantalos, täytä maljasi" on oksymoron, retorinen mahdottomuuskuvio. Se viittaa runon kirjoittamisen eli janon tyydyttävän maljan nauttimisen mahdottomuuteen. Puhuja kärsii Tantaloksen tuskia: kaiken lunastava runous on lähellä mutta saavuttamattomissa, aivan kuten myytissä vesi ja hedelmät pakenevat ikuiseen nälkään ja janoon tuomitun Tantaloksen ulottuvilta. Tämä metalyyrinen runo asettuu selkeästi osaston alun sublimaatiota vastaan. Kuolema ei merkitse valoon yhtymistä, vaan oman voittajanmerkin, "seppeleen" heittämistä "ikuiseen tyhjyyteen". Puhuja tunnustaa, että kuolema tuhoaa taiteen ylevyyden ja lupaukset, tekee niistä jätettä ("trasor", "smulor") ja banaaleja lappusia.

Runon puhujan voi oikeutetusti tulkita runojen laatijaksi, jopa kirjallisesti alter egoksi, kuten deiktinen kysymys "Är detta dikter?" paljastaa. Hän ei näe työllään olevan todellista arvoa: se pysähtyy omaan mahdottomuuteensa. Tämä on selkeä murtuma voitonvarmuudessa. Edes runous ei välttämättä ole ikuista. Kuolema ja mahdottomuus pyyhkivät niin runoilijan kuin tämän aikaansaannokset tyhjyyteen.

Osaston kuudes runo "Den förlorade kronan" jatkaa pessimististä valitusta ja alistuvia kysymyksiä sanastoltaan vain astetta ylevämmässä rekisterissä kuin edellinen runo. Puhuja kuvaa oman kutsumuksensa kadottamisesta syntyvää surua. Kaiken löydettyään hän joutuu ehkä tyytymään kohtaloonsa, kieltämään voittajan roolinsa ja oppimaan nöyryyttä:

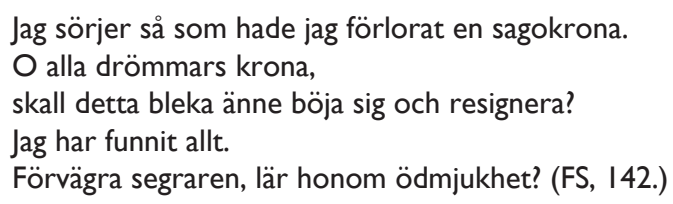

Nämä kaksi runoa purkavat teoksessa voimalla luotua poikkeusyksilön ja voittajan kuvaa. Pettersson ei viittaa analyysissaan sanallakaan näihin runoihin katsomuksellisen jännitteen luojina, mikä mielestäni paljastaa hänen tulkintansa valikoivuuden. Oman tulkintani mukaan ei ole perusteltu pitää tätä tulevaisuususkon ja kuolevaisuudenkokemuksen välistä jännitettä ironisena leikkinä tietoisesti tuotetuilla konstruktioilla. Pikemminkin toisen osaston runoissa tapahtuva oman kuolevaisuuden käsittely saa aikaan pysähtymisen, jossa aiemmin konstruoitujen roolien ja nyt hyvin arkisena näyttäytyvän todellisuuden välille repeää kuilu. Runojen tunnelma heittelehtii ekstaasista epätoivoon, ja puhujan paikoittainen epäröinti ja kysymykset alkavat heijastaa ohittamatonta ahdistusta. 
Tässä paljastuvat tyhjyydenkokemuksina ilmenevän kuolemansairauden todelliset kasvot: runoudella ei ole voimaa luoda kuolemaa voittavia satuja. Puhuja tiedostaa selvästi asian laidan: "skall detta bleka änne böja sig och resignera?" (FS, I42.)

Kun "Tantalus, fyll din bägare" ja "Den förlorade kronan" merkitsevät voitokkuuden romahdusta, yrittävät osaston kolme seuraavaa runoa jälleen nousua hurmokseen. "Eros tempel", "Solen" ja "Nätet" luovat vastakohdan kahden edeltävän runon epätoivolle. "Eros tempel" ja "Solen" vievät takaisin sublimoituun todellisuuteen, puhujan henkilökohtaiseen satumaailmaan, jossa ristiriidat lakkaavat. Puhujan kuolevaisuuden kokemus käännetään fantasiaksi Eros-jumalan ja feminiinisen auringon ("hon") antamasta autuudesta, johon muilla ei ole osaa. On huomattava, että pelkkä fantasia antautumisesta riittää puhujalle, vaikka Eroksen vaatimukset, halu ja ajatukset jäävät tälle arvoitukseksi: "Vad hans läppar bjuda, har ingen förstått, / vad han innerst tänker, vet ingen. [...] Vi känna ej hans lust - - - - - - -." (FS, I42.)

"Eros tempel" vahvistaa ajatusta Eroksesta tuntemattomana mutta voimakkaana jumalana, joka eroaa "nuorten ruumiiden huolettomasta leikistä". Antautuminen Erokselle merkitsee tulena olemista ja siten myös tuhoutumista, ja sitä puhuja tahtoo enemmän kuin mitään muuta: "Vi Eros lekkamrater, vi vilja endast ett: / bli eld utav din eld och brinna upp." (FS, I42.) "Solen" -runon puhuja kuvaa vastaavaa kokemusta auringon syleilyssä: "En gång / skall jag spinna mig in i solen som en fluga i bärnsten, / för eftervärlden blir det ingen klenod, / men jag har varit i sällhetens glödgade ugn.” (FS, I43.)

Osaston toiseksi viimeinen runo "Nätet" muistuttaa ensimmäisen osaston runoja, jotka luonnostelevat valoisaa tulevaisuutta ja uutta yhteisöllisyyttä: "Det finnes någonstädes gudar bakom de tätaste skogarna, / vi irrande människobarn vilja ingen annanstädes än dit. / UpP att söka framtidens flammande sol bortom skogen." (FS, I43.) Runon puhuja esittäytyy jälleen profeetallisena hahmona, nietzscheläisin kuvin luotuna kalastajattarena, joka kokoaa opetuslastensa joukot verkollaan satupadolle, lähemmäs tulevaisuutta (ks. Nietzsche 1995: 331; Tideström 1949: 85; Haapala 2005: 377-378).

Osaston päättää "Uppståndelsemysterium”, jonka alle on merkitty sulkuihin "Tillfällighetsdikt". Runo poikkeaa niin puhujan asenteen kuin kuvaston osalta jokaisesta kokoelman aiemmasta runosta. "Tilapäisyys"12 on ymmärrettävä osaston puhujan ottaman uuden asennon tai hetkellisen roolin perusteella. Runo tuo käänteen niin ekspressionistis-nietzscheläiseen uhoon kuin joidenkin runojen pessimistiseen tulevaisuudennäkymään. Se osoittaa hetkeksi tien ulos tämänpuoleisen elämän dialektiikasta, jossa elämän merkityksettömyyden muuntaminen ylevöitetyiksi näyiksi on ainoa, mutta epävarma vaihtoehto. Samoin se kumoaa ahdistavan, kuolemaan päättyvän elämän ajatuksen.

12 "Uppståndelsemysterium" on kenties tilapäisruno Framtidens skugga -kokoelman toisessa osastossa, mutta se ennakoi kolmannen osaston resignaatiota. Ennen kaikkea Södergranin viimeisenä vuotenaan kirjoittamien runojen kannalta sen suostuminen ylösnousemukseen ja ikuisuuteen on olennainen. Runo on ensimmäinen selkeästi kristillinen juonne Södergranin tuotannossa. 
"Uppståndelsemysterium" on kristillinen lohdutuksen runo. Se päättyy ajatukseen kuolemattomuudesta ja ikuisesta elämästä, johon Jumala kutsuu lapsensa ja johon runon naishahmo suostuu:

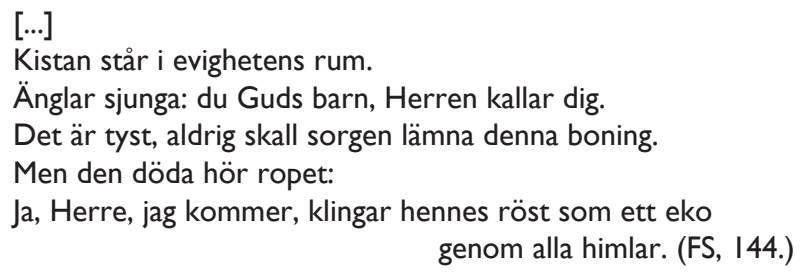

Kuolema ei ole runossa autuaan tuhoutumisen tai kivettymisen hetki, kuten osaston aiemmissa runoissa. Nyt kuolema pyhittyy: maailma muuttuu "ikuisuuden huoneeksi”, jossa kuuluvat Jumalan, hänen lapsensa ja enkeleiden äänet, kun fyysinen elämä on päättynyt. Päätyykö osaston puhuja tarjoamaan itselleen ensi kertaa uskonnollisen lohdutuksen mahdollisuutta taiteen kuolemattomuuden näyttäydyttyä keinotekoisena? Näin tulkiten runo ennakoisi Södergranin viimeisenä elinvuotenaan kirjoittamien runojen tuonpuoleiseen suuntautumista. Merkintä "Tillfällighetsdikt" voi olla kuitenkin myös ironinen kommentti siitä, että puhujalla on heikko hetki, jolloin hän ajattelee jopa kristillistä vaihtoehtoa.

Toisin kuin Pettersson esittää jo osaston alkua analysoidessaan (200l: 53), toisessa osastossa ei näy ekstaasin laukeamista resignaatioksi. Se esiintyy vasta epätoivottuna mahdollisuutena "Den förlorade kronan” -runon kysymyksessä. En myöskään näe Petterssonin (200 I: 55) tapaan, että osaston päättävän runon kuva tuonpuoleisesta täydentäisi kokoelman yritystä tuoda transsendenssi maan päälle. Pikemminkin osasto tarjoaa joukon jännittyneitä, aina yhtä tilapäisiä ja keskenään yhteismitattomia yrityksiä ratkaista kuolevaisuuden ongelma. Pettersson (200I: 55) myöntää yllättäen, että osaston puhujan ahtaassa tilanteessa ironia väistyy aiempaa voimakkaammin, joskaan ei kokonaan taka-alalle. Tähän Petterssonin tulkintaan voin yhtyä.

\section{Älvdrottningens spira och andra dikter: illuusion murtuminen}

Kolmannessa osastossa Älvdrottningens spira och andra dikter haetaan välitöntä irtiottoa toisen osaston lopun uskonnollisen runon maailmasta. Katsomuksellinen vastakkaisuus näkyy siinä, miten osaston aloitus, kolmena laajana fragmenttina etenevä "Älvdrottningens spira" käsittelee "Uppståndelsemysterium" -runon elämän ja kuoleman tematiikkaa. Osaston avaava minämuotoinen runo tarttuu sekin kuolevan naishahmon tilanteeseen, mutta tarjoaa aivan toisenlaista ratkaisua.

"Älvdrottningens spira" sisältää kokoelman runoista runsaimmin satuelementtejä. Kyseessä ei kuitenkaan ole satu, vaan etäännytetty kuvaus olemassaolon kamppailusta. Tämä rooliruno dramatisoi arkussaan makaavan, hädin tuskin elossa olevan naishahmon ajatukset tai sisäisen puheen. Runossa vastakkain ovat kuviteltu rakkaus ylläpitäjineen ja kuolema. Lyhyesti sanoen runo on elämän ja kuoleman välimaastossa uinuvan puhujan fantasia paluusta elämään. 
Kun toisen osaston viimeisen runon äänet kuuluvat Jumalalle, enkeleille ja Jumalan lapselle ja tilana on huone, hallitsevat tätä runoa naishahmon "rinnan äänet". Siinä kuuluu keijukaiskuningattaren huilunkaltainen puhe sekä keijujen sanat puutarhassa: "Till älvdrottningen, till älvdrottningen! skriar det ur ditt / bröst. / Älvdrottning, älvdrottning, svara mig på blanka dagen.” (FS, I47.)

Runon kaksi ensimmäistä fragmenttia kuvaavat naisen herättämisyrityksiä. Sulhanen epäonnistuu ja menettää uskonsa. Pelastajaksi tulee keijukaiskuningatar joukkoineen. Kuningattaren elähdyttämä puhuja saa lopulta takaisin myös sulhasensa. Sulhanen vahvistaa uudelleen liittonsa naisen kanssa. Runo kolmas fragmentti on sulhasen ja runon naishahmon eroottinen vuoropuhelu, jossa syntyy lupaus läheisyydestä.

Ebba Witt-Brattström (1997: 330-332) tulkitsee runon allegoriaksi naisruumiista. Hänen mukaansa runon keskeinen ajatus on, että naissubjekti pysyy kuolleena niin kauan kuin se antaa objektivoida itsensä kulttuurisin klisein. Sadunomaisen runon voi kuitenkin lukea kokoelmakontekstissa allegoriana runouden ja siinä luonnosteltujen hahmojen kyvystä herättää naishahmo eloon ja toteuttaa hänen fantasiansa elämän jatkumisesta. Näin tulkittuna runo jatkaa toisen osaston avaamaa yritystä löytää runoudesta lääke kuolevaisuuteen. Asia tulee erityisen hyvin esiin runon loppufragmentissa, naishahmon lausumassa repliikissä. Kuoleman kohtaamisen ajatus siirretään syrjään elämän voiman kuvilla:

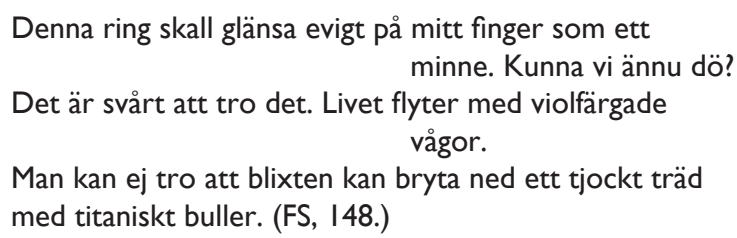

Miksi tällainen fantasia on sijoitettu teoksen päättävän osaston alkuun? Ensi kertaa kokoelmassa on läsnä fyysinen eroottisuus henkisempien elementtien rinnalla. Viimeisen osaston alussa runojen puhujat tekevätkin kaikkensa kumotakseen elämän ja kuoleman välisen rajan tai pikemminkin yrittävät lykätä sen kaukaisuuteen. "Älvdrottningens spira" -runossa sulhasen rakkaus kuitenkin osoittautuu riittämättömäksi. Naishahmo toki tunnistaa sulhasensa hellät ja eroottiset kosketukset, tai äidilliset kosketukset, kuten Witt-Brattström tulkitsee (1997: 33 I), mutta vasta kuningattaren voima palauttaa hänet takaisin elämään. Näin runossa kietoutuvat toisiinsa sukupuolten välinen eroottinen voima ja fantasian Eros eli feminiiniseen aurinkoon vertautuva keijukaiskuningatar. Runo ylittää kokoelman Erosrunojen tapaan uskon (hetero)seksuaalisen rakkauden voimaan.

"Älvdrottningens spira" -runon jälkeen kolmas osasto jatkaa aiemmissa osastoissa esiintyneiden puhetilanteiden ja teemojen variointia. Monin kohdin se vahvistaa uskoa luomisvoimaan ja taiteelliseen ekstaasiin, mutta toisaalta usko runouteen ei ole ehdotonta. Osaston runot eivät muodosta selkeää synteesiä, joka sovittaisi toisessa osastossa syvenneet ristiriidat ja eri suuntiin vetävät näkemykset. Päinvastoin, kokoelman loppua kohden epäröinti lisääntyy. Toisaalta illuusioiden murentuessa lopullisesti osastoon syntyy aiemmin näkemättömiä asennonvaihdoksia ja resignaatiota, joka toisessa osastossa nähtiin lähinnä alistumisena. 
En käy seuraavassa lävitse osaston jokaista runoa yhtä tarkasti kuin kahden ensimmäisen osaston kohdalla, sillä käsiteltävät runot, joita on yli kaksikymmentä, toistavat pitkälti aiempien osastojen asetelmia. Sen sijaan keskityn päälinjoihin ja murtumakohtiin, jotka paljastavat, mistä kokoelman laajimmassa osastossa on kyse.

Kolmannen osaston runot voidaan jaotella edelleen pääosin kahteen puhuja-asemaan: voitokkaiden ja tulevaisuutta luovien puhujien puheenvuoroihin sekä runouden mahdollisuuksia pohtiviin metalyyrisiin runoihin. Kolmas osasto on sekoitus ensimmäisestä osastosta tuttuja abstrakteja konstellaatioita ja roolirunoja sekä toisessa osastossa mukaan tulleita henkilökohtaisempia runoja. Aluksi pääosassa ovat poikkeusyksilöiden puhumat runot. Ne alkavat heti osaston toisesta runosta "Vattenfallet", joka käynnistyy puhujan luomisahdistuksen kuvauksella ja kysymyksillä omasta tulevaisuudesta, mutta vaihtuu vähitellen nautintoon ja hurmaan.

Kolmannesta runosta kuudenteen kyseessä on toisessa osastossa alkanut Eros-runojen sarja "Eros hemlighet", "Eros skapar världen ny", "Blixten" ja "Instinkt". Runot kuvaavat androgyynin jumaluuden voimaa ja puhujan kohtaamisia Eroksen kanssa: "Jag känner dig, Eros - / du är icke man och kvinna / du är den kraft, / som sitter nedhukad i templet, / för att resande sig [...] / slunga ut förkunnelsens träffande ord över världen / ur det allsmäktiga templets dörr.” (FS, I49.)

Eros-sarjan teemoja jatkavat ekstaasia, valtaa, voitokasta ruumista ja tulevaisuuden yksilöitä kuvaavat runot 7-II eli "Ensamhet", "Den starkes kropp", "Aning", "Vid soluppgång" ja "O du mitt hjärtas vidd...”. Runoissa toistuvat eri variaatioin kokoelmassa esitetyt ratkaisut ruumiillisuuden ja kuolevaisuuden kysymyksiin: ruumis ja kuoleman kokemus muunnetaan ylimaallisiksi, kosmisten voimien ja mysteereiden kohtaamispaikoiksi. Runojen puhujan voi ajatella jatkuvasti yhdeksi ja samaksi. Kun aiemmissa osastoissa poikkeusyksilö, voitokas puhuja, vielä odotti pääsyä jumalten seuraan, alkaa saman puhuja-aseman jakava puhuja kolmannessa osastossa muuttua jumalaksi. "O du mitt hjärtas vidd..." päättyy paljonpuhuvasti sanoihin: "Jag är en gud i vilken ovädren rasa, / med sugande ögon drager jag alla in i min själ" (FS, I52).

Kahdestoista runo "Materialism" tuo muutoksen ekstaattiseen puheeseen. Se jatkaa edellisten runojen kuvastoa, mutta murtaa kuvia uuteen asentoon, illuusiot riisuvaksi reflektioksi. Siteeraan runon kokonaisuudessaan, sillä se tuo viimeiseen osastoon monia jännitteitä ja purkaa luotuja asemia:

\footnotetext{
För att icke dö måste jag vara viljan till makt. För att undgå atomernas kamp under upplösning. Jag är en kemisk massa. Jag vet så väl, jag tror icke på sken och själ, lekarnas lek är mig så främmande. Lekarnas lek, jag leker dig och tror ej ett ögonblick. Lekarnas lek, du smakar gott, du doftar underbart, dock finnes ingen själ och har det aldrig funnits någon

Det är sken, sken, sken och idel lek. (FS, I53.) själ.
} 
Runon puhuja nimeää vallantahdon ("viljan till makt") elämänvoimakseen tai pikemminkin kuoleman estäjäksi. ${ }^{13}$ Valta on keskeinen käsite osaston viidessä "Materialism" -runoa edeltäneessä runossa ("Instinkt", "Ensamhet", "Den starkes kropp", "Aning", "Vid soluppgång"). Vallantahto ei ole Södergranilla sosiaalinen voima, vaan suuntautuu nimenomaan ruumiin sähköistämiseen kosmisilla energioilla. Siten se ehkäisee kuoleman. Vallantahto auttaa kestämään atomien hajoamiskamppailun eli vie ajatukset pois oman yksilöllisyyden ja ruumiin hajoamisesta. Kolmannessa säkeessä runon puhuja ottaa aiempaa rationaalisemman kannan ja määrittelee itsensä "kemialliseksi massaksi”. Tämä materialistinen näkemys on hänelle varmaa tietoa, ja se pohjustaa väitettä: "jag tror icke på sken och själ, / lekarnas lek är mig så främmande."

Säkeet ovat monimielisiä. Sielulla tarkoitetaan yleensä ihmisen tajuntaa tai aineetonta olemusta, joka pitää yllä henkisiä toimintoja ja ilmiöitä. Usein se käsitetään itsenäiseksi olennoksi, jonka uskotaan kuolemassa eroavan ruumiista ja jatkavan olemassaoloaan. Tällaisen ajatuksen puhuja kieltää. Mutta onko runossa kyse pelkästään esimerkiksi kristillisen ikuisen sielun kieltämisestä ja sen ja runouden leikin vastakkainasettelusta, vai kieltääkö puhuja uskonsa myös runouden leikkiin? Varmaa on, että sekä "själ" että "sken" ovat puhujalle vieraita. Ne eivät voi taata pysyvää aineetonta identiteettiä, joka lisäksi puhujan mukaan on harhaa. Ainoa myönteinen tunnustus on, että puhuja uskoo olevansa kemiallista massaa.

Kokoelmakontekstissa sana "sken", varsinkin kun sitä täsmennetään sanoilla "lekarnas lek", ei tulkintani mukaan kuitenkaan viittaa pelkästään harhaiseen ajatukseen sielusta vaan myös runouteen ja sen hahmojen loistoon. "Sken" on kokoelmassa attribuutti, jolla kuvataan voitokkaiden hahmojen ohjautumista ainoaan oikeaan suuntaan ("vältrande sig / i underbara öden, / rullar planeternas oräkneliga skara förbi / mot ett ljust sken i väster - / möjlighetens enda utstakade väg." runossa "Planeterna", FS, I39). Toisaalta sillä luonnehditaan myös tähtien tuhovoimaa ja pettävyyttä ("Varje stjärna kommer tågande som ett rött sken ur / fjärran / för att förstöra, äta upp, förbränna, utöva sin makt." runossa "Fientliga stjärnor", FS, I37). "Eros tempel” -runossa (FS, I42) "meitä" eli voittajia kutsutaan nimellä "Vi Eros lekkamrater", jotka leikkivät Södergranin (1919/1996: 140) vallantahdoksi (Wille zur Macht) henkilöimän Eroksen kanssa. "Älvdrottningens spira" -runossa sulhanen hellittelee kuoleman voittanutta naishahmoa nimellä "Du leksakernas leksak" (FS, I47).

\footnotetext{
13 Tahdon käsite ("vilja") oli tuttu Södergranille Arthur Schopenhauerin ajattelusta, jossa tahto elää merkitsee samalla olemassaolon tuskaa. Luopuminen tahdosta tarkoittaa vapautumista elämän rajoituksista. Toinen, Södergranille luontevampi viitekohta tahdolle oli Nietzschen filosofia, jonka Södergran otti ohjenuorakseen toisesta kokoelmastaan alkaen. Nietzsche kehitteli Schopenhauerin pessimististä filosofiaa ja nimesi elämän perusvoimaksi tahdon valtaan (Wille zur Macht). Nietzschen mukaan kaikki elävä tahtoo valtaanpääsyä. Tahtominen ei ole kielteinen käsite, kuten Schopenhauerin filosofiassa, vaan myönteistä voimaa, elämän luonne: "Vain siinä, missä on elämä, on myös tahtoa: mutta ei vain elämäntahtoa, vaan [...] vallantahtoa" (Nietzsche 1883-9|/1995: 156). Södergran täsmentää kirjeissään, että hänen runoutensa Eros on juuri tämä nietzscheläinen Wille zur Macht (Södergran 1919/1996: 102-103, 140).
} 
Runon jatko vahvistaa kaksoisasetelmaa. Sielu ja runous ovat olennaisia esteettisen, ruumiillisia aistimuksia tarjoavan ja kokoavan voimansa vuoksi: puhuja ryhtyy leikkien leikkiin, vaikkei usko siihen hetkeäkään. Olennainen paljastuu puhuttelussa: "du smakar gott, du doftar underbart”. Välittömiä, miellyttäviä aistimuksia kuvaavan säkeen jälkeen tulee sana "dock". Se kääntää ajatuksen jälleen siihen, ettei puhuja usko minkäänlaisen, ei edes runollisen performanssin tuottaman autenttiseen identiteettiin: "dock finnes ingen själ och har det aldrig funnits någon / själ." Sielu on retorisesti painokkaan viimeisen säkeen mukaan aina vain harhaa ja leikkiä ("idel lek"). ${ }^{14}$

Leikkiä, jossa pyritään kuolemattomuuteen ja loistoon, varjostaa epäusko. "Leikkien leikki” on kaksoisside, joka syntyy sekä pyrkimyksestä kuolemattomuuteen ("själ") että loistoon ("sken"). On tärkeää huomata, että "Materialism" on kokoelman viimeinen runo, jota Pettersson analysoi. Samaan tapaan kuin oma tulkintani runosta, hänen tulkintansa korostaa ironisuutta: "Materialism" asettaa toivon tuonpuoleisesta elämästä ironiseen valoon, mutta samoin se ironisoi nietzscheläistä vallantahtoa valittuna ja vakaumuksellisena elämänasenteena. Sekin on vain tietoista leikkiä. (Pettersson 200I: 56.)

Voidaan syystä kysyä, miksi Pettersson lopettaa kokoelman tulkinnan tähän? Luultavasti paras selitys asialle on se, ettei Petterssonin kuvausmalli enää riittävästi selitä teoksen loppuosaa, jossa synkän itseironian korvaavat muunlaiset suhtautumistavat.

Koska epäilys leikkien leikin näennäisyyttä kohtaan esitetään kokoelman yhdessä metalyyrisimmässä runossa, ei epäily ole lähtökohdiltaan ulkoistettua, jollekin roolihahmolle osoitettu asennoitumistapa. Kamppailu runouden mielekkyyden ja mielettömyyden välillä siirtyy yhä voimakkaammin kokoelman henkilökohtaisimpiin runoihin. "Materialism" -runosta lähtien voiman juhlinta säröilee kokoelmassa yhä pahemmin, vaikka jo seuraava runo "Extas" pyrkii takaisin autuuden piiriin. Runon puhuja julistaa koko muun maailman tuomituksi, koska se ei pysty kuulemaan autuuden ääniä ja kokemaan ekstaasia. Puhuja kuvaa ekstaasia liki samoin sanoin kuin "Materialism" -runon puhuja atomien hajoamiskamppailua: "genom mina läppar strömmar hettan av en gud, / alla mina atomer äro åtskilda och stå i brand..." (FS, I54.)

"Extas" on malliesimerkki siitä kvasitranssendentaalisesta suuntautumisesta, joka hallitsee Södergranin kokoelmia Septemberlyran, Rosenaltaret ja osin kokoelmaa Framtidens skugga (ks. Haapala 2005: 3|6-3|8). Usko ekstaasiin alkaa kuitenkin murtua. Vahvintakin ekstaasin kuvausta reunustaa tietoisuus kuvittelun illusorisuudesta. Petterssonin ajatus siitä, että "Materialism" -runon puhuja suhtautuu ironisesti nietzscheläiseen filosofiaan, on hieman puutteellinen. Vaikka jotkin Södergranin runot voi oikeutetusti tulkita itseironisiksi, on Nietzschen

14 "Materialism" -runon valossa aiempienkin runojen ekstaasien uskottavuus alkaa säröillä. "Eros skapar världen ny" -runon lopetus korostaa sokeuden leikkiä, jota usko vallantahtoon tarkoittaa. Siinä Eros, elämän johtava voima, personoidaan nuoreksi jättiläiseksi, jonka esittämä satu on sokea, vailla tunnistettavaa päämäärää: "Den unga jätten anar ren den stora blinda saga, / han åter en gång spelar.” 
mukaan taiteessa kyse nimenomaan halusta uskoa illuusioon, sillä taide auttaa ihmistä antamaan elämälle merkityksen, jota sillä ei annettuna ole. ${ }^{15}$

\section{Älvdrottningens spira och andra dikter: totuus ja resignaatio}

"Extas" -runoa seuraavassa runossa "Hamlet" tulevaisuuden suunnan pohdinnalle antaa painoa kysymys totuudesta. Pako ekstaasiin ei tule enää kysymykseen:

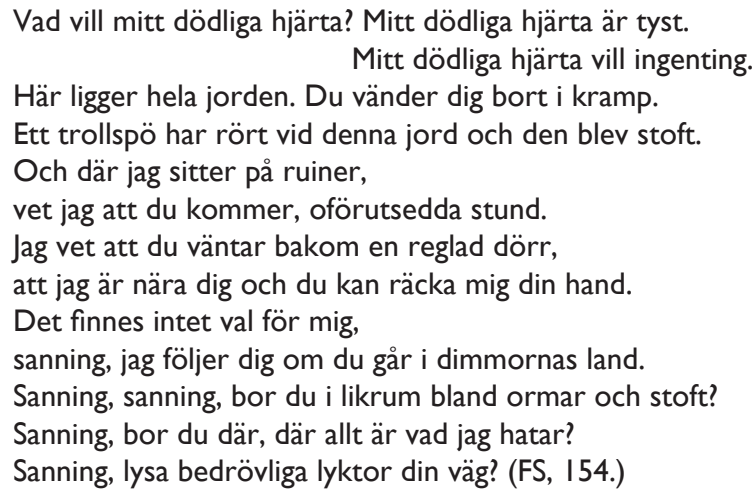

"Hamlet" merkitsee käännekohtaa kolmannessa osastossa. Kyse ei ole pelkästä metalyriikasta, vaan puhujan eksistentiaalisesta suhteesta totuuteen. Totuus on kokoelmassa aivan uusi sana ja samalla uusi eksistenssikategoria, johon puhuja olemistaan ja valintojaan suhteuttaa. Runon puhujan voi nähdä samantapaisessa tilanteessa kuin ensimmäisen osaston runon "Wallensteinprofil" puhuja oli. Enää kyse ei ole siitä, että taide tarvitsisi vastavoimia, kuiluja ja pahuutta, noustakseen korkeuksiin. Kyse on itse totuuden kohtaamisesta ja seuraamisesta.

Kun William Shakespearen Hamlet esittää kuuluisan yksinpuhelunsa aluksi kysymyksen "To be, or not to be, that is the question?" ja reflektoi kuolemaa ja itsemurhaa, Södergranin runon puhuja pohtii "kuolevaisen sydämensä" tahtoa ja toteaa, ettei se tahdo mitään. Sille ei ole mitään, mihin suuntautua, sen maailma on tuhoutunut.

Tilanne pelkistyy kuvaan pölyksi muuttuneesta maasta ja kouristuneesta pois kääntymisestä. Taikasauva on pyyhkinyt kaiken tomuksi. Runon puhetilanteen voi tulkita juuri kääntymisen hetkenä. Aiemmin osastossa itseään manifestoineet voimat ovat rauenneet ja on aika nähdä totuus. Minä näkee elämänsä paljaana ja ensi kertaa kuin ulkopuolelta: "Här ligger hela jorden. Du vänder dig bort i kramp." (FS, I54.)

Runon loppua hallitsee totuuden apostrofinen puhuttelu. Puhuja kuvaa totuuden ensin "aavistamattomana hetkenä", joka odottaa puhujaa ja joka on niin lähellä, että se voi koskettaa häntä. Totuus on jotakin, jonka seuraamisesta puhuja ei voi kieltäytyä, merkitsipä se mitä hyvänsä.

\footnotetext{
${ }^{15}$ Runouden kykyä ylevöittää olemassaolo voitaisiin kehitellä edelleen keskustelemalla Holger Lillqvistin väitöskirjan (200I) pohjalta esteettisen idealismin perinteestä ja siitä, kuinka Södergran käsittelee tämänpuoleisen ja transsendentin tai oman ajatukseni mukaan tämänpuoleisen ja kvasitranssendentaalisen suhdetta. Olen selvittänyt asiaa väitöskirjassani perinpohjaisesti suhteessa nietzscheläiseen dityrambiin, jonka näen Södergranille ominaiseksi lajiksi (Haapala 2005: I35-|40, |46-I52).
} 
Puhuja käsittää, että seuraaminen voi olla aivan muuta kuin kulkemista kohti yleviä kosmisia näkyjä. Totuus voi olla tekemisissä kuoleman ja kaiken sen kanssa, mitä puhuja vihaa. Puhetilanteen taustaksi aktivoituu kokoelman avausruno "Mysteriet", jonka puhuja tahtoi nietzscheläisittäin polkea pienuutta ja taikauskon eli uskonnon käärmettä ja pistää sen pään miekalla puhki. Nyt tilanne on toinen.

Esittäessään kysymyksiä totuuden paikoista puhuja käyttää pitkälti samoja kuvia, joilla Nietzsche luonnehtii Epäjumalten hämärä -pamfletissaan kristinuskoa ${ }^{16}$,"maanalaista", käärmeiden pesistä ja katakombeista alkunsa saanutta uskontoa, joka korostaa ihmisten tasavertaisuutta (Nietzsche 1889/1995: 64). Runon kuvat usvien maasta, hautakammiosta, käärmeistä ja tomusta jäävät irrallisiksi, ellei lukija tunne Södergranille tyypillistä retoriikkaa. "Hamlet" -runon esittämä totuus saa puhujassa aikaan tilan, jossa valinnanvaihtoehtoja ei ole. On valittava totuus, vaikka se merkitsisi epämiellyttävien ja puhujan siihen saakka vihaamien asioiden, kuten kuolevaisuuden ja uskonnollisen totuuden, kohtaamista, kääntymistä kosmisista visioista kohti maata.

"Hamlet" -runon esittämä vakaumus totuuden seuraamisesta jää vaikuttamaan osaston loppuun saakka. Sitä ei himmennä edes voittajaroolin hahmottelu kahdesta säkeistökokonaisuudesta muodostuvassa roolirunossa "Hyacinten", joka korostaa herooista murtumattomuutta. Runossa puhuva hahmo eli kukka tavoittelee yhteyttä feminiiniseen aurinkoon ja kuningattareen, mutta mukaan tulee ehdollisuus: "Bryt mig till smycke åt en drottning. / Om det finnes en sorglös och obekymrad drottning, / må hon hålla hyacinten som en spira i sin hand, / vårens sköra symbol, besläktad med solen.” (FS, I55.)

Itse asiassa "Hamlet" -runoa seuraavissa runoissa "Hyacinten" ja "Fyra små dikter" jatkuu laajempi asenteen muutos. Runot muuttuvat aiempaa resignoituneimmiksi ja suhteellisuudentajuisemmiksi. Poikkeusyksilöiden puhuja-asemaa luonnehtinut väkivaltainen tulevaisuuden muovaaminen ei enää hallitse. Pikemminkin puhuja hakeutuu luonnon symbolien äärelle. "Fyra små dikter" sekä sitä seuraavat "Animalisk hymn" ja "Sol" nostavat esiin toisessa osastossa alkaneen aurinkoon tuhoutumisen teeman, mutta enää kyse ei ole tulevaisuuteen työnnetystä kuolemasta tai ekstaattisesta uhosta, vaan tyytymisestä nyt-hetkeen. Myös olemassaolon loppumista puhujat odottavat tyynesti. Resignoituminen merkitsee oman ylpeyden jättämistä ja luonnonvoimien pyyteetöntä kokemista. Tässä syntyy kokonaan uudenlainen, nykyhetkeen ja luontoon tyytyvien puhujien puhuja-asema.

"Fyra små dikter" -sarjan toisessa osassa puhuja toteaa olemuksestaan:

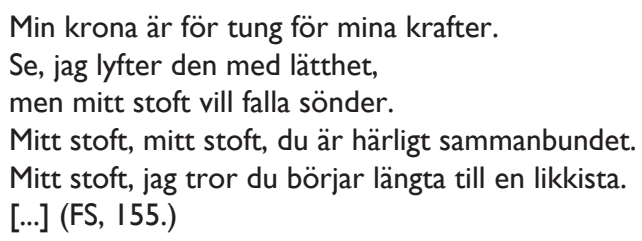

16 Esimerkiksi saman osaston runossa "Ensamhet" suhtaudutaan torjuvasti kristinuskoon: "Kristna spöken sitta i alla hjärtan och sträcka ut / armodets händer." 
Puhuja toteaa, että hän on voimakkaampi kuin hänen hajoamaisillaan oleva ruumiinsa. Tämä on ensimmäinen kohta kokoelmassa, jolloin kokevaa ja kuolevaa ruumista ei sublimoida. Vaikka "Små fyra dikter" -sarjan kolmannessa ja neljännessä runossa kuvataan elämänkaltaista voitonriemua ja myötäkäymistä, jotka syntyvät yhteydestä aurinkoon, ei niiden pohjavireenä ole enää utopia tulevaisuudesta vaan tyytyväisyys nykyhetkeen ja konkreettiseen aurinkoon. Niinpä "Animalisk hymn" -runossa puhuja voikin sanoa lapsenkaltaista iloa tuntien:

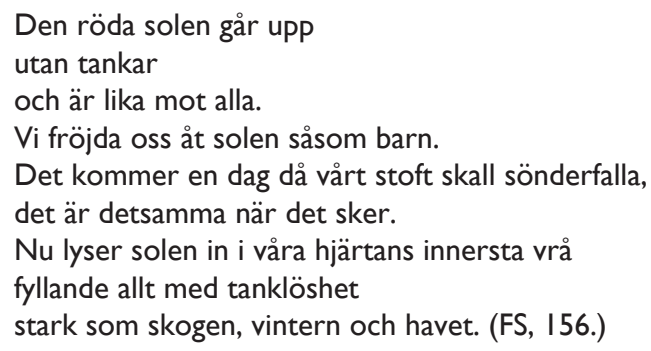

Tieto omasta kuolevaisuudesta otetaan tyynesti vastaan. Kuolevaisuus käsitetään olennaisesti kaikkien elävien osaksi ("alla", "vi", "vår"), sen suhteen ei ole poikkeusyksilöitä. Seuraavassa runossa "Sol" puhuja jopa opettaa yhä utopioissa hekumoivaa ja tulevaisuutta kohti aggressiivisesti kurottavaa sydäntään nöyrtymään ja tuntemaan auringon voiman sellaisena kuin se on: "O du övermodigaste bland hjärtan, sträck ut dina armar / mot solen, / fall på knä och låt ditt bröst bli genomträngt av solen, / solen." (FS, I57.)

Näin "Hamlet" -runon totuuden kohtaamisesta alkanut muutos tuo kokoelman kolmanteen osastoon aivan uudenlaisen äänen. Kyse ei ole aggressiivisen ironisesta suhteesta omiin utopioihin, kuten "Materialism" -runossa, tai kuoleman herättämästä epätoivosta vaan myöntymisestä kuolevaisuuteen. Tämä käännekohta on myös tulkinnan kannalta tärkeä. Se osoittaa, ettei Södergranin kokoelmaa voi lukea vain yhden, esimerkiksi ekstaasin ja kitkerän itseironian sävyttämän tulkinnallisen kuvion lävitse, kuten Pettersson tekee (200I: 60), vaan kokoelmassa käydään läpi monia hienovaraisia siirtymiä, joista itseironia selittää vain osan. Aivan yhtä tärkeitä ovat ekstaasin ohittava totuus sekä siitä seuraava lempeä, suhteellisuudentajuinen huumori ja oman kuolevaisuuden myöntäminen. Tässä kokoelmakokonaisuuden tarkka lukeminen näyttää voimansa: se tarjoaa nyansoidumman tulkinnan ja pystyy haastamaan aiemmat mallit.

Seuraavat kaksi runoa "Beslut" ja "Blixtens trängtan" muodostavat jälleen parin. Nämä metalyyriset runot tekevät tiliä runouden kirjoittamisesta ja olemuksesta. "Hamlet" -runossa alkanut totuuden kohtaaminen vaikuttaa myös siihen, kuinka puhuja suhtautuu runouden kirjoittamiseen. "Beslut" on jännitteinen. Runoa voi lukea kollaasina, joka syntyy sosiaalisista rooleista tehdyistä huomioista sekä retorisesti käytetyistä mytologian elementeistä. Jälkimmäiset liukuvat päällekkäin kirjoittamisesta tehdyn päätöksen kanssa:

Jag är en mycket mogen människa,

men ingen känner mig.

Mina vänner göra sig en falsk bild av mig.

Jag är icke tam. 


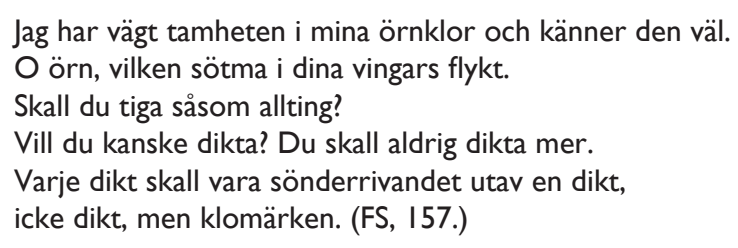

Kotka on kreikkalaisessa mytologiassa taivaan jumalan Jupiterin tai Zeuksen symboli. Tässä runossa majesteettinen petoeläin on ennen kaikkea kokoelmasta tutun, voitokkaan tulevaisuuden näkijän symboli. Puhuja toteaa ensin, että ystävien hänestä luoma kuva on väärä, hän on kypsä ja tietää itse paremmin, sillä hän on punninnut kesyyden kotkankynsillään. Seuraavaksi puhuja ottaa etäisyyttä itsestään ja ylistää kotkan lennon kauneutta - kyse on oman persoonan symbolisesta avaamisesta kotkatunnuksella. Apostrofit kotkalle auttavat puhujaa esittämään itselleen olennaisia kysymyksiä, kuten "Skall du tiga såsom allting?", "Vill du kanske dikta?" Aivan kuten "Hamlet" -runossa, puhuja etäännyttää itsensä sinäksi totuuden ja runouden olennaiset kysymykset kohdatessaan. Vastaus kysymyksiin on dramaattinen ja jyrkkä. Runoilu saa loppua, koska kyseessä on toiminta, joka tuhoaa itsensä ja jättää merkin väkivallasta, kynnenjäljet.

"Beslut" -runon metalyyrinen puhuja rinnastuu päätelmineen "Tantalus, fyll din bägare" -runon puhujaan. Kun "Tantalus, fyll din bägare" -runo korostaa runojen banaaliutta ja runoilun mahdottomuutta, kommentoi "Beslut" -runon puhuja kirjoittamisen tuhoisuutta. Näin runot kuuluvat samaan metalyyriseen puhuja-asemaan ja edustavat sen eri puolia, joissa kummassakin runouden eettinen päätös on paradoksaalisesti jättää hyvästit runoudelle, tai ainakin tietynlaiselle kirjoittamiselle.

"Blixtens trängtan" tuo näyttämölle vielä hetkeksi voimakkaan tulevaisuuden hahmon kokemuksen: "Jag är örn. / Det är min bekännelse. / Icke diktare, / aldrig något annat." (FS, I58.) Jälleen puhuja sanoutuu paradoksaalisesti irti runoilijan roolista, aivan kuten edellisessä runossa, vaikka hän yhä ilmaisee itseään runolla ja kuvaa yksityisen ekstaasinsa merkitystä. Ekstaattisessa näkemisessä, kotkanlennossa, tapahtuu aina sama ikuinen mysteeri: "För mig finns ingenting annat än kretsa i örneflykten. / Vad sker i örneflykten? / Alltid detsamma, det eviga. / En blixt skjuter ner på himlen i ändlös begärlighet / älskande hemlighetsfullt som då en ny värld blir till.” (FS, I58.) Tämä luova mysteeri on suhteellistettu runossa yksityiseksi kokemukseksi. Sillä ei yritetä saada aikaan mitään maailman mittakaavassa, sitä ei suostuta jatkamaan.

Samankaltainen maltillinen suhteutuminen omaan kutsumukseen näkyy osaston seuraavassa, toiseksi viimeisessä runossa "Den stora trädgården", jota voi pitää rinnakkaisena toisen osaston vastaavassa kohdassa esiintyvälle runolle "Nätet". Runon puhuja pitää yhä olennaisena yhteisöä, joka tarjoaa maailmalle uuden elämän, mutta fanaattinen sävy on muuttunut maanläheisemmäksi. Enää kyse ei ole varmasta tulevaisuudesta, vaan haaveesta: "Om jag hade en stor trädgård [...]” (FS, I58). Puutarhaansa puhuja kutsuisi sisarusparvensa, "kodittomat vaeltajat", "alasti ja ryysyissä" kulkijat. Heidän suurin omaisuutensa on heidän henkinen elämänsä ja sisaruus, jota he tuntevat kaltaisiaan kohtaan. Puhuja 
ei enää muovaa ihmiskuntaa väkivalloin, toisin kuin kokoelman ensimmäisen osaston voimakkaan poikkeusyksilön puhuja-aseman jakajat. Vaikka kodittomat vaeltajat eroavat yhä muusta ihmiskunnasta, heille lahjoittaminen on tärkeää, ei ottaminen. On huomattava, että myös suhde kolmannen osaston keskeisiin sanoihin on muuttunut. "Materialism" -runossa harhaksi tuomittu käsite "sielu" ("själ") on jälleen pätevä ja tulee osaksi lahjoittamista: "Vi hava ingenting annat att skaffa med den övriga / skapelsen / än att giva den vår själ” (FS, 158). Käänne on yllättävä. Runous tuhoisana maailmanvalloituksena muuttuu hiljaisen, eristetyn paikan etsimiseksi: "Vi skola bygga ett galler kring vår trädgård / att intet ljud från världen når oss. / Ur vår tysta trädgård / skola vi giva världen ett nytt liv." (FS, 159.)

Kokoelman viimeinen runo on aina tärkeä rakenteellisen kuvion sulkija. Yhtä lailla se koettelee sitä, miten lukija on onnistunut kokoelmaa varten valitsemissaan tulkintastrategioissa (Smith 1978: I3; Haapala 2012: 182). Framtidens skugga -kokoelman päättävä runo "Stjärnan" tuo yhteen monia kokoelmassa esiintyneitä suhteutumistapoja:

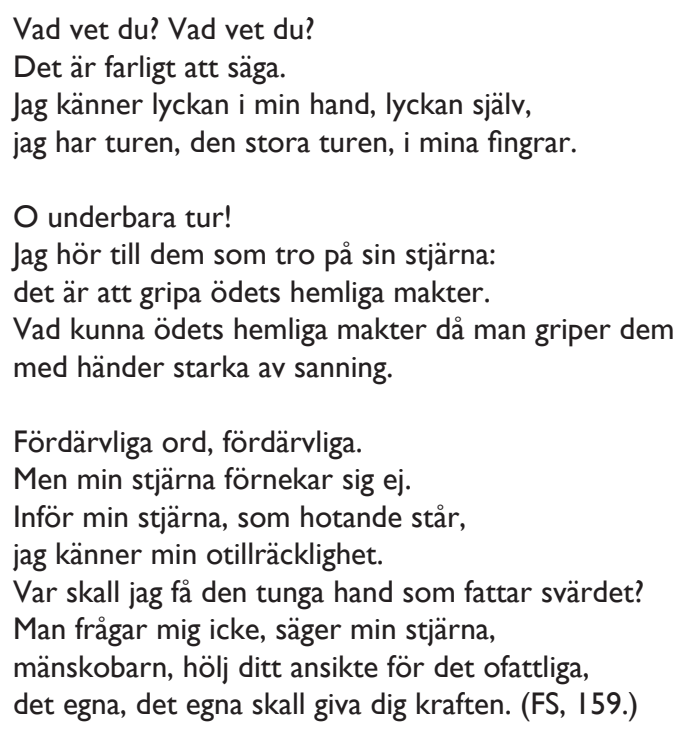

Ensimmäisessä säkeistössä puhuja hyödyntää samankaltaisia kysymyksiä kuin "Hamlet" -runon puhuja. Nyt kysymys tahdosta on vaihtunut kysymykseen tiedosta. Puhujan mukaan on vaarallista paljastaa tietonsa. Sen sijaan hän ylistää onnea.

Toisessa säkeistössä onni kohdentuu: kyse on puhujan uskosta omaan tähteen. Puhujan "tähti" vaikuttaa henkilökohtaiselta vakaumukselta, jonka nojalla hän voi tarttua kiinni omaan kohtaloonsa. Puhujan jatkaessa kysymystä kohtalon toteuttamisesta, tulee mukaan "Hamlet" -runossa esiin noussut kysymys totuudesta: "Vad kunna ödets hemliga makter då man griper dem / med händer starka av sanning". Runon puhujalle totuus, ei esimerkiksi ekstaasi, on tullut olennaiseksi. Totuus vahvistaa asioihin tarttumista ja yksilöllisen olemassaolon toteuttamista.

Viimeinen säkeistö on monitulkintainen ja jättää puhujan hieman ristiriitaiseen tilaan. Ensin hän kuvaa sanoja, jotka tuottavat tuhoa. Asetelma muistuttaa runosta "Beslut", jonka puhuja päätti hylätä runou- 
den sen tuhovoiman vuoksi. Sitten puhuja luonnehtii uhkaavana kohoavaa kohtalon tähteään ja riittämättömyyttään sen edessä: vaikka runous olisi jäämässä taakse, on puhujalla yhä kohtalonsa, johon totuus häntä vaatii.

Runon lopun vuoropuhelu tähden kanssa muistuttaa kokoelman alusta, ensimmäisestä runosta "Mysteriet", jonka puhuja riehui miekkoineen ja tuhosi maailman pienuutta. Nyt "Stjärnan" -runon puhuja kysyy, mistä hän löytää raskaan käden eli asenteen toimintaan. Tähti antaa paradoksaalisen vastauksen: "Man frågar mig icke." Kohtalolta ei siis kysytä. Tähden lopullinen vastaus, joka päättää kokoelman, on yllättävä: "mänskobarn, hölj ditt ansikte för det ofattliga, / det egna, det egna skall giva dig kraften." Vastaus sointuu yhteen kolmannessa osastossa yhä enemmän tilaa saavan resignaation kanssa. Tähden neuvo on, ettei ihmisen tule suunnata katsettaan asioihin, joita hän ei voi käsittää, vaan keskittyä siihen mitä hänellä on. Näin ekstaasit ja tulevaisuuden utopiat vaihtuvat totuudeksi ja elämäksi, joka puhujalla yhä on. Tätä on uusi amor fati, oman elämänsä rakastaminen oma kohtalonaan.

\section{Framtidens skugga itseironian ylittäjänä ja nietzscheläisyyden murtajana}

Framtidens skugga -kokoelmasta tekemäni puhujuuden ja asennonvaihtojen analyysin jälkeen on syytä pohtia, millainen aatteellinen peruskuvio teoksessa toteutuu. On selvää, että kokoelmassa on kyse Södergranille tyypillisestä roolien konstruoinnista ja jännitteisen kokonaisuuden hahmottelusta. Teos on esimerkillinen näyte kuviteltujen olentojen ja puheaktien luomisesta.

Torsten Pettersson ehdotti, että Södergranin koko tuotannossa näkyy itseironia ja luotujen aatteellisten kantojen suhteellistaminen. Tämä teesi pätee vain osin Framtidens skugga -kokoelmaan, samoin kuin Södergranin muihin teoksiin. Käytännössä Södergranin kokoelman analysointi itseironisena asennoitumisena Petterssonin tapaan on hankalaa jo kokoelman puhujuuden monihahmotteisuuden vuoksi. Ironian tarkastelu vaatisi Petterssonilta lisäkehittelyjä ja vastauksia sellaisiin kysymyksiin kuin "Mikä on itse, joka ironisoituu ja mistä näkökulmasta se ironisoituu?". Juuri runosta toiseen vaihtuvien suhtautumistapojen ja niiden tulkinnanvaraisuuden vuoksi olen joutunut oman analyysini edetessä olettamaan erilaisia puhujia ja puhuja-asemia. Toisaalta olen havainnut myös yhtenäisempiä jaksoja mitä pidemmälle kokoelmassa olen edennyt. Ehdotukseni onkin, että kokoelman puhujat ja retoriset puhuja-asemat ovat viime kädessä pelkistettävissä muutamaan. Kokoelman metalyyrisissä, runoutta ja sen arvoa pohtivissa runoissa esiintyy keskeislyyrinen puhuja, jonka voi ajatella luonnostelleen teoksen muut runot. Tämän puhujan tuottamia ovat sekä roolirunot että voimakkaan poikkeusyksilön puhuja-asemasta käsin esitetyt tulevaisuuden utopiat. Ne muodostavat suurimman osa teoksen runoista. Puhuja vastaa myös resignaation ja henkilökohtaisen luopumisen runoista, joista osa kuuluu metalyyrisiin runoihin. Roolirunot painottuvat teoksen ensimmäisessä osastossa, joskin ne jatkuvat läpi kokoelman. Metalyyrinen puhuja tulee varsinaisesti esiin 
toisessa osastossa ja vahvistuu jälleen kolmannen osaston loppupuolella, mutta ulottaa yhtä kaikki valtansa koko kokoelmaan. Tällainen puhujuutta koskeva jaottelu tuntuu perustellulta, vaikka kokoelmassa raja erilaisia ekstaattisia kokemuksia ja tulevaisuuden utopioita korostavien runojen sekä metalyyristen runojen välillä on toisinaan tulkinnanvarainen.

Selkeimmin ero roolirunojen ja metalyyrisen runojen välillä syntyy siitä, että metalyyrisissä runoissa puhuja on tietoinen runojen tehdystä luonteesta sekä siitä, että tuota tekemistä arvioidaan suhteessa runon ulkopuoliseen todellisuuteen: arkeen, luontoon, kuolemaan ja sosiaalisiin rooleihin. Roolirunojen puhujilla tällaista tietoisuutta runon tehdystä luonteesta ei juuri ole. Roolirunot ja puhuja-asemat ovat tämän kokoelman varsinaisen puhujan eksperimenttejä, joiden avulla tämä luonnostelee ja työstää olemisen mahdollisuuksia ja jännitteitä.

Vaikka Pettersson ei asiaa erikseen mainitse, hänen korostamansa itseironia sisältyy Södergraniin voimakkaasti vaikuttaneen Friedrich Nietzschen taidekäsitykseen, joka oli Södergranin runoudelle ja pyrkimyksille merkityksekäs aatteellinen viitekohta. Nietzschen mukaan taide on lumetta (Schein), mutta se on hyväksi yksilön terveydelle pelastaessaan ihmisen olemassaolon mielettömyydeltä ja kauhuilta (Nietzsche 1987: 39-40, 53-54). Petterssonin idea (2001: 60) ekstaasin ja itseironian sekoittumisesta toisiinsa selittää vain rajatusti Södergranin Framtidens skugga -kokoelmaa. Se selventää lähinnä ekstaattisten visioiden runojen sekä niitä ironisesti kommentoivien runojen suhdetta, selvimpänä tapauksena "Materialism”. Ironinen kaksoisside ei kuitenkaan toimi niissä runoissa ja eksistenssisuhteissa, jotka totuuden kysyminen ja resignaatio avaavat kokoelmaan "Hamlet" -runosta eteenpäin. Kysymys totuudesta jättää taakseen ironian ja "leikkien leikin".

"Hamlet" -runon puhujan totuutta kohti kääntymisen jälkeen kokoelmassa on yhä selvempää, että tahto ja voima, joiden piti runouden avulla kohdentua maailmaan muuttamiseen, ovat pitkälti voimattomia. Runo runolta käy yhä painokkaammin ilmi, ettei ekstaattisesta runoudesta ole tulevaisuuden takaajaksi. Se ei onnistu kumoamaan todellisuutta ja sen äärimmäistä pistettä, kuolemaa. Poikkeusyksilöiden ruumiillistama runous jää hypoteettiseksi, "Tantalus, fyll din bägare" -runon mukaan jopa epäonnistuneeksi kirjaukseksi. Runoilijan roolissa esiintyvä metalyyrinen puhuja luopuu runoista ja runoilijana olemisesta menettämättä silti kutsumustaan.

Oman analyysini mukaan Framtidens skugga -kokoelmaa ja sen puhujaproblematiikkaa luonnehtii parhaiten ajatus metalyyrisestä puhujasta, joka antautuu oman kuolevaisuutensa kokemukselle, tiedostaa ja esittää sen. Framtidens skugga -kokoelman nimeen kiteytyy yhtä aikaa runollinen tulevaisuuden odotus ja kuoleman varjo. Niiden ristiriita on ratkaisematon, kunnes sen edessä resignoidutaan. Runous piirtää esiin epäonnistumisen, hämmennyksen ja tietoisuuden hallitsemattomasta lopusta aina siihen saakka, kun se ei enää yritä tehdä mahdotonta vaan antautuu totuudelle ja kuolevaisuuden rajaamalle elämälle.

Esittämäni analyysi haastaa myös Södergranin tuotannon periodisoinnin: Framtidens skugga ei edusta puhtaasti ekspressionistista, 
nietzscheläistä vaihetta, vaan itse asiassa hajottaa sen ja sisältää piirteitä, jotka tulevat täysin selviksi Södergranin viimeisissä runoissa. Tätä taustaa vasten ei ole vaikea nähdä, että tähden vastaus kokoelman viimeisessä runossa "Stjärnan" avaa väylän Landet som icke är -kokoelman luonnonystävyyttä, totuutta ja Jumalan suojelusta korostaviin runoihin.

\section{LÄHTEET}

Broomans, Petra, Adriaan van der Hoeven, Jytte Kronig (toim.) 1993: A Changing Image. Looking for a New Perspective on the Work of a Finnish Avant-garde Poet. Groningen: RUG, Werkgroep Vrouwenstudies Letteren.

Brunner, Ernst 1985: Till fots genom solsystemen. En studie i Edith Södergrans expressionism. Stockholm: Bonniers.

Enckell, Olof 1949: Esteticism och nietzscheanism i Edith Södergrans lyrik. Studier i finlandssvensk modernism (I). Helsingfors: Svenska litteratursällskapet i Finland.

Evers, Ulla 1992: Hettan av en gud. En studie i skapandetemat hos Edith Södergran. Göteborg: Skrifter utgivna av Litteraturvetenskapliga institutionen vid Göteborgs universitet.

Fraistat, Neil 1985: The Poem and the Book. Interpreting Collections of Romantic Poetry. Chapel Hill \& London: The University of North Carolina Press.

Fraistat, Neil (toim.) 1986: Poems in Their Place. The Intertextuality and the Order of Poetic Collections. Chapel Hill \& London: The University of North Carolina Press.

Haapala, Vesa 2005: Kaipaus ja kielto. Edith Södergranin Dikter-kokoelman poetiikkaa. Helsinki: Suomalaisen Kirjallisuuden Seura.

Haapala, Vesa 20II: "Edith Södergrans diktmontage Dikter". Teoksessa Arne Toftegaard Pedersen (toim.), På fria villkor. Edith Södergran studier s. 57-78. Helsingfors: Svenska litteratursällskapet i Finland \& Bokförlaget Atlantis.

Haapala, Vesa 2012: "Teoskokonaisuuden runousoppia: Esimerkkinä Katri Valan Kaukainen puutarha". Teoksessa Siru Kainulainen, Karoliina Lummaa ja Katja Seutu (toim.), Työmaana runous: Runoudentutkimuksen nykysuuntauksia s. 159-185. Helsinki: Suomalaisen Kirjallisuuden Seura.

Hackman, Boel 2000: Jag kan sjunga hur jag vill. Tankevärld och konstsyn $i$ Edith Södergrans diktning. Helsingfors: Söderströms.

Hedberg, Johan 1991: Eros skapar världen ny. Apokalyps och pånyttfödelse i Edith Södergrans lyrik. Göteborg: Daidalos.

Hulle, Dirk van 2006: "Growth and the Grid: Organic Vs Constructivist Conceptions of Poetry" s. 49I-507, Neophilologus 2006: 90.

Hühn, Peter \& Kiefer, Jens 20I I: The Narratological Analysis of Lyric Poetry. Studies in English Poetry from the $16^{\text {th }}$ to the $20^{\text {th }}$ Century. Kääntänyt Alastair Matthews. Berlin: Walter de Gruyter.

Häll, Jan 2006: Vägen till landet som icke är. En essä om Edith Södergran och Rudolf Steiner. Helsingfors \& Stockholm: Svenska Litteratursällskapet i Finland \& Bokförlaget Atlantis. 
Jones, W. Glyn \& Branch, M. A. (toim.) 1992: Edith Södergran. Nine Essays on Her Life and Work. London \& Helsinki: School of Slavonic and East European Studies, University of London \& Suomalaisen Kirjallisuuden Seura.

Lilja Norrlind, Eva 198I: Studier i svensk fri vers. Den fria versen hos Vilhelm Ekelund och Edith Södergran. Göteborg: Skrifter utgivna av litteraturvetenskapliga institutionen vid Göteborgs Universitet.

Lillqvist, Holger 200 I: Avgrund och paradis. Studier i den estetiska idealismens litterära tradition med särskild hänsyn till Edith Södergran. Helsingfors: Svenska litteratursällskapet i Finland.

Nietzsche, Friedrich 1883-91/1995: Näin puhui Zarathustra. Kirja kaikille eikä kenellekään. Suomentanut J. A. Hollo. Helsinki: Otava.

Nietzsche, Friedrich 1889/1995: Epäjumalten hämärä, Eli miten vasaralla filosofoidaan. Suomentanut Markku Saarinen. Helsinki: Unio Mystica.

Pettersson, Torsen 200I: Gåtans namn. Tankens och känslans mönster hos nio finlandssvenska modernister. Helsingfors \& Stockholm: Svenska litteratursällskapet i Finland \& Bokförlaget Atlantis.

Phelan, James 2008: "The Beginning of Beloved: A Rhetorical Approach". Teoksessa Brian Richardsson (toim.), Narrative Beginnings: Theories and Practices s. 195-212. Lincoln \& London: University of Nebraska Press.

Rahikainen, Agneta 2014: Kampen om Edith. Biografi och myt om Edith Södergran. Helsingfors: Schildts \& Söderströms.

Richardson, Brian 2008: "A Theory of Narrative Beginnings of 'The Dead' and Molloy". Teoksessa Brian Richardsson (toim.), Narrative Beginnings: Theories and Practices s. 113-126. Lincoln \& London: University of Nebraska Press.

Suchsland, Inge 1990: "At elske og at kunne."Weiblichkeit und symbolische Ordnung in der Lyric von Edith Södergran. Frankfurt am Main: Peter Lang.

Tideström, Gunnar 1949: Edith Södergran. Helsingfors: Wahlström \& Wittstrand.

Schoolfield, George C. 1984: Edith Södergran. Modernist Poet in Finland. Westport, Connecticut, London: Greenwood Press.

Södergran, Edith 1990: Dikter och aforismer. Samlade skrifter I. Toimittanut Holger Lillqvist. Helsingfors: Svenska litteratursällskapet i Finland.

Södergran, Edith 1996: Brev. Samlade skrifter 2. Toimittanut Agneta Rahikainen. Helsingfors: Svenska litteratursällskapet i Finland.

Witt-Brattström, Ebba 1997: Ediths jag. Edith Södergran och modernismens födelse. Stockholm: Nordstedts.

\section{Kirjoittaja}

Vesa Haapala, FT, yliopistonlehtori, Helsingin yliopisto, kotimainen kirjallisuus (vesa.haapala[at]helsinki.fi) 